American University Washington College of Law

Digital Commons @ American University Washington College of

Law

Articles in Law Reviews \& Other Academic Journals

Scholarship \& Research

2018

The Peace vs. Justice Debate and the Syrian Crisis

Paul Williams

Lisa Dicker

C. Danae Paterson

Follow this and additional works at: https://digitalcommons.wcl.american.edu/facsch_lawrev

Part of the Human Rights Law Commons, International Humanitarian Law Commons, International Law Commons, Law and Gender Commons, and the Military, War, and Peace Commons 


\title{
THE PEACE VS. JUSTICE PUZZLE AND THE SYRIAN CRISIS
}

\author{
Paul R. Williams, ${ }^{*}$ Lisa K. Dicker, ${ }^{* *}$ C. Danae Paterson ${ }^{* * *}$
}

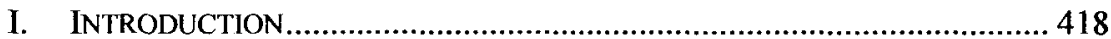

II. THE "PEACE-FIRST" APPROACH ................................................ 420

A. Prioritizing Ending the Conflict ................................................. 421

B. Benefits of the Peace-First Approach ....................................... 422

1. Saving Lives......................................................................... 422

2. Ending Harm to the Environment and Infrastructure ................... 422

3. Promoting Reconciliation........................................................ 423

C. Achieving Peace-First in Practice ............................................... 423

1. Singular Objective of Ending the Conflict ................................... 423

2. Negotiating with the Guys with Guns ...................................... 424

3. Accommodation and Appeasement ........................................... 424

4. Minimizing Justice ................................................................ 425

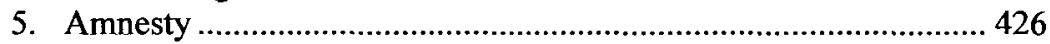

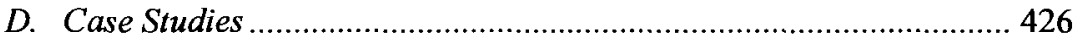

* Rebecca I. Grazier Professorship in Law and International Relations at American University. Professor Williams teaches at the School of International Service and the Washington College of Law and also directs the joint JD/MA program in International Relations. He holds a Ph.D from Cambridge University, J.D. from Stanford Law School, and B.A from UC Davis. Professor Williams is co-founder of the Public International Law \& Policy Group (PILPG), a non-profit group, which provides pro bono legal assistance to states and governments involved in peace negotiations, post-conflict constitution drafting, and war crimes prosecutions. Over the course of his legal practice, Professor Williams has assisted with over two dozen peace negotiations and post conflict constitutions. Professor Williams has advised governments across Europe, Asia, as well as North and Sub-Saharan Africa on state recognition, self-determination and state succession issues, and on drafting and implementation of post-conflict constitutions. Among its projects, PILPG currently provides pro bono legal assistance to the Syrian opposition as they engage in the peace process. The authors are extremely grateful for the research and editing assistance provided by Jonathan Heinz, Dalya Kefi, Megan Masingill, Emily Nevala, and Nikki Waxman.

** Graduate of Harvard Law School, J.D. and University of Tennessee, B.A. Lisa Dicker's legal and academic work focus on negotiation and conflict and dispute resolution, particularly as they relate to crisis, armed violence, and peace processes. She is currently on PILPG's Syria Negotiations Support team, advising the Syrian opposition in the peace process and PILP's Tanzania team, working with the Tanzanian Commission on Human Rights and Good Governance on efforts to counter and prevent violent extremism.

*** Graduate of Harvard Law School, J.D., and holds an MSc in Comparative Politics and Nationalism from the London School of Economics. Danae Paterson specializes in peace negotiations, international humanitarian law, and human rights. She is the Program Manager for PILPG's Syria Negotiations Support team and works to advise the Syrian opposition in the peace process, providing on-site support in Istanbul, Doha, Washington, and Geneva. She is also Program Manager for PILPG's work in Yemen to support the inclusion of women, youth, and persons with disability in the peace process, and Program Manager for PILPG's work to incorporate victim participation in emerging hybrid war crimes tribunals. 
III. THE "JUSTICE-FIRST” APPROACH ................................................ 430

A. Prioritizing Accountability ..................................................... 430

B. Benefits of the Justice-First Approach .......................................... 431

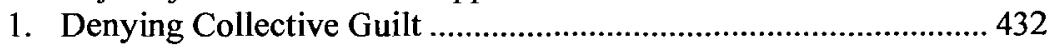

2. Delegitimizing Institutions and War Criminals........................... 432

3. Establishing an Accurate Historical Record................................ 432

4. Facilitating Victim Catharsis.................................................. 432

5. Deterrence ............................................................................ 433

C. Achieving Justice-First in Practice ......................................... 434

1. The International Criminal Court ............................................... 435

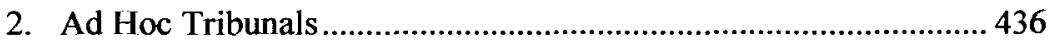

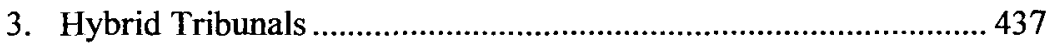

4. Domestic Tribunals ................................................................. 438

5. Universal Jurisdiction ............................................................. 438

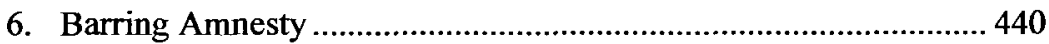

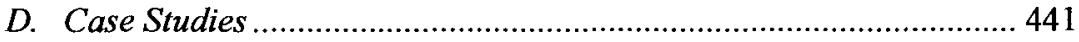

IV. PEACE WITH JUSTICE ......................................................................... 443

A. Methods to Meet the Needs of the State Post-Conflict ................... 445

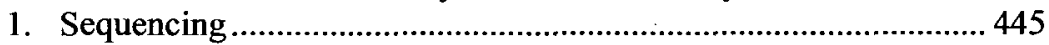

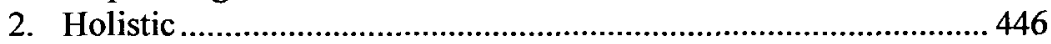

3. Non-State Justice Mechanisms...................................................... 446

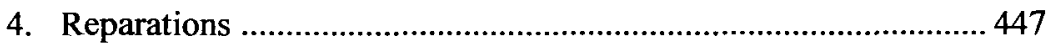

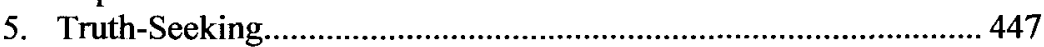

B. Peace with Justice in Colombia .................................................... 448

C. Peace with Justice in Sierra Leone .................................................. 453

D. Peace with Justice in the Côte d'Ivoire ...........................................454

E. Peace with Justice in Cambodia .....................................................456

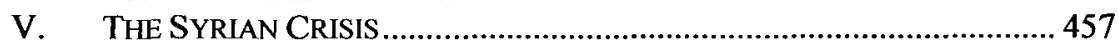

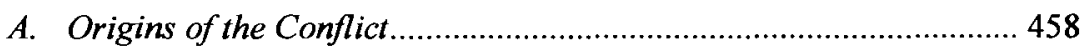

B. Syria-A Multi-Dimensional Spill-In Conflict ................................ 459

C. Seeking to Weave Justice into the Syria Peace Process ................... 465

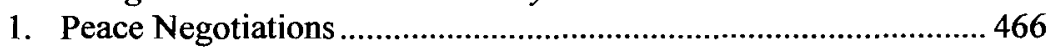

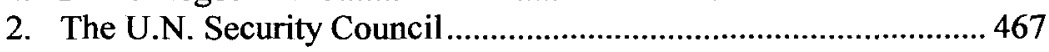

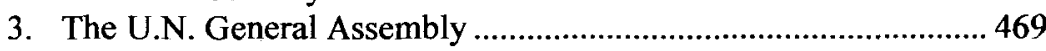

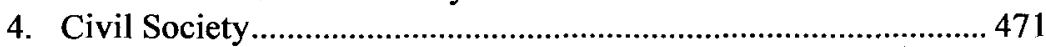

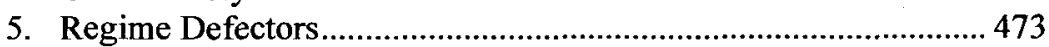

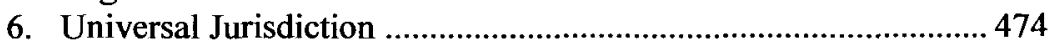

7. The International Criminal Court ............................................. 475

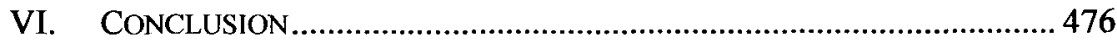

\section{INTRODUCTION}

Those involved in peace negotiations often face the dilemma of balancing demands for justice with the imperative of stopping the conflict as quickly as possible. There are abiding ethical and moral debates surrounding this tension between peace and justice. In Syria-where the 
death toll has exceeded $470,000,11$ million have been displaced, and there are over 14,000 documented cases of death by torture ${ }^{1}$ - the peace versus justice puzzle is a living dilemma with which those involved in the peace process grapple with on a daily basis.

Is it morally permissible to allow conflict (and the attendant human suffering) to continue, so as to advance the possibility of achieving justice in the form of accountability against the perpetrators of the violence? Alternatively, if justice is set aside to achieve peace more rapidly, and accountability is delayed or even prevented, is the resulting harm (including a possible return to conflict) acceptable? The debate between peace and justice lives in delegation meetings, offices of legal advisors, foreign ministries, and state governments. In the midst of a crisis, negotiators and those who advise them often must confront the tradeoff between peace and justice. Indeed, the questions being debated in the Syrian peace process reflect this lingering puzzle that negotiators have grappled with for decades. Individuals must determine their priorities in this regard and create a pragmatic strategy towards achieving that outcome. It is important to understand the primary tenants of the peace versus justice puzzle in order for those involved in a particular peace process to best solve this puzzle.

This article does not propose to answer the weighty question of which approach best resolves the conundrum of peace and justice, nor does the article intend to recommend a solution to the complex intricacies of attempting to merge the two together. Rather, this article strives to examine a timely facet of this multidimensional puzzle: how to successfully accommodate the desire for justice by artfully weaving tenets of accountability into a peace process, without undermining a peace process. One answer to this pressing question is that the best method is to avoid justice in the peace process altogether. This is the peace-first approach. Another, competing answer, is that the most salient choice is to treat justice as a foundational building block of the peace process. This is the justicefirst approach. There is also a third answer, which suggests that the most effective method for solving the puzzle is to strike a delicate blend of justice with peace.

As illustrated by the experiences of a rich array of countries that have grappled with these questions, there is no clear consensus on the degree of justice that ought to be brought in to a peace process, nor when and how justice ought to be introduced. There is, however, a clearer sense that however these questions are ultimately resolved, there should be at least a modicum of justice. Although there is an increasing trend towards a

1. HUMAN RightS WATCH, WORLD REPORT: EVENTS OF 2016571 (2017), https://www. hrw.org/sites/default/files/world_report_download/wr2017-web.pdf [hereinafter HRW WORLD REPORT: EVENTS OF 2016]. 
holistic role of justice in the peace process, the question of "how much justice" remains unresolved.

The Syrian conflict provides a particularly useful foil in examining this puzzle. After initial uncertainty as to which approach would take primacy in the Syrian peace process, the failure of pivotal efforts to introduce accountability measures at the United Nations (U.N.) Security Council placed the conflict squarely with the peace-first approach. Since then, however, actors have persistently pursued efforts to weave in justice into the peace process, through efforts to document violations, to lay the foundation for victim catharsis, and to engage in new and creative options for prosecutorial activity.

This article will first explore the peace-first approach: the priorities of the supporters of this approach, the potential advantages to pursuing peacefirst, and case studies of peace processes that have successfully and unsuccessfully followed this approach. Next, this article will examine the justice-first approach in a similar manner. After analyzing the assumed dichotomy between peace and justice, the article will explore the potential (although limited) overlap between these two approaches, identifying the perspective that justice and peace may be compatible in cases where justice is artfully woven into peace. The article will also identify the limitations to this approach. Finally, the article will contextualize the peace versus justice puzzle, with reference to the Syrian conflict. Through an exploration of each of these topics, the article seeks to examine the puzzle of accommodating a drive for accountability, without undermining the ability of the parties to halt a conflict.

\section{THE "PEACE-FIRST" APPROACH}

"The quest for justice for yesterday's victims of atrocities should not be pursued in such a manner that it makes today's living the dead of tomorrow." Anonymous United Nations Official ${ }^{2}$

The peace-first approach can best be understood by first understanding the general perspective and priorities of the approach and then diving deeper to examine how the approach is implemented in practice. This section will begin by discussing the tenants of the peace-first approach and identifying the primary categories of practitioners that support it. Next, the section will explore the advantages of the peace-first approach in peace processes. The section will then focus on actions that can be taken to implement the peace-first approach in the peace process. Finally, to illuminate the nuances of the approach, this section will explore the case

2. Anonymous, Human Rights in Peace Negotiations, 18 HUM. RTS. Q. 249, 258 (1996) [hereinafter Human Rights in Peace Negotiations]. 
studies of South Africa, Bougainville, and Yemen and how the peace-first approach manifested in each context.

\section{A. Prioritizing Ending the Conflict}

As suggested by its name, the peace-first approach prioritizes ending the conflict above all other interests. ${ }^{3}$ The singular role of negotiators is to seek an agreement that brings the most immediate end to the violence. ${ }^{4}$ All other goals and concerns that may impede immediate peace should be pushed aside. In this way, the approach is single-minded and pragmatic: peace is the priority and any obstacle to peace should be avoided or eliminated.

There is a tension between ideal outcomes in peace processes and the outcomes that parties are in fact able to agree to at that moment. ${ }^{5}$ The peace-first approach will always opt for the latter-the most immediate resolution of the conflict should be pursued. ${ }^{6}$ Rather than allowing the violence to continue while negotiators pursue a more ideal resolution, ceasing the violence takes precedence. Indeed, achieving justice against individuals and parties that committed atrocities during the conflict may be a goal of some parties in the peace process, but it may not be possible to achieve peace while also pursuing justice. ${ }^{7}$ As with any other interest, if the pursuit of justice will prolong the conflict, justice should not be sought. ${ }^{8}$

The peace-first approach is often associated with parties to the peace process who have committed atrocities, with the aggressor and frequently with mediators. The peace negotiator's role is to end the conflict, not to assume the role of a prosecutor and assign responsibility or call for justice. ${ }^{9}$ As articulated by United States (U.S.) Ambassador Richard Holbrooke-a key figure in mediating the Bosnia's Dayton Accords-when asked as to why he continuously declined to indicate Serbian President Slobodan Milosevic's guilt for the war and atrocities in the former Yugoslavia, ${ }^{10}$

3. Id. at 251 .

4. Id. at $255-56$.

5. Id. at $249,252$.

6. See id. at 252 .

7. I. William Zartman, Negotiating Forward-and Backward-Looking Outcomes, in PEACE VERSUS Justice: Negotlating Forward-AND BaCKWARD-LOOKING OutComes 1, 6 (I. William Zartman \& Victor Kremenyuk eds., 2005).

8. Id.

9. Human Rights in Peace Negotiations, supra note 2, at 256.

10. Michael P. Scharf \& Paul R. Williams, Functions of Justice and Anti-Justice in the PeaceBuilding Process, 35 CASE W. RES. J. INT'L L. 161, 186 (2003). 
"[t]his is tough slogging, and my job was not to make moral judgments, [ . . .] and the highest goal here was to avoid war and bring peace."11

\section{B. Benefits of the Peace-First Approach}

The peace-first approach's prioritization of ending the conflict has advantages. Bringing immediate peace saves lives and ends human suffering. ${ }^{12}$ Additionally, peace ends harm to the environment and destruction of infrastructure, which are by-products of the conflict, and reconstruction efforts may begin sooner. ${ }^{13}$ The focus on peace also encourages national reconciliation and social reconciliation. ${ }^{14}$

\section{Saving Lives}

Ending the conflict as soon as possible results in lives being saved and human suffering ceasing more rapidly. Pursuing objectives other than peace may prolong the conflict and thus result in more casualties and harm. Although atrocities may have been committed, ending the conflict as quickly as possible prevents more from occurring. ${ }^{15}$

\section{Ending Harm to the Environment and Infrastructure}

Conflicts have disastrous impacts on the natural environment and infrastructure. Achieving peace not only ends the harm being caused to the environment and infrastructure, but also allows reconstruction efforts to begin in the state sooner than if the conflict was to continue. By prioritizing peace, the natural environment can be protected and efforts to heal it can be initiated. Additionally, prioritizing peace allows the state and its people to begin rebuilding its infrastructure-such as homes, hospitals, schools, roads, and power supplies-sooner. More immediate

11. Hearings on the Nomination of Hon. Richard C. Holbrooke to Serve as U.S. Ambassador to the United Nations: Hearings Before the Comm. on Foreign Rel. U.S. Sen., 106th Cong. 101-02 (1999) (statement of Hon. Richard C. Holbrooke).

12. Human Rights in Peace Negotiations, supra note 2, at 250.

13. U.N., Dep't of Econ \& Soc. Affairs, Peacebuilding Support Off., Peacebuilding Commission, Working Group on Lessons Learned, Economic Revitalization in Peacebuilding and the Development of Service Based Infrastructure 1, 4 (Nov. 22, 2010), http://www.un.org/en/peacebuilding/ pdf/doc_wgll/desa_pbso_background_paper.pdf [hereinafter Revitalization in Peacebuilding].

14. See Orlaith Minogue, Peace vs. Justice: The Utility of Amnesties, 29 CRIM. JUST. ETHICS 306, 308 (2010); Dwight G. Newman, The Rome Statute, Some Reservations Concerning Amnesties, and A Distributive Problem, 20 AM. U. INT'L L. REV. 293, 304-06 (2005).

15. See Human Rights in Peace Negotiations, supra note 2, at 258. 
reconstruction in turn prevents the compounding of harmful byproducts of the conflict, such as lack of access to medical attention or education. ${ }^{16}$

\section{Promoting Reconciliation}

Achieving peace without pursuing justice can lead to national and social reconciliation. Undertaking prosecutions can allow animosity between the national and societal factions to continue to fester. Granting amnesty and achieving peace may instead lead to forgiveness and reconciliation. ${ }^{17}$ Offering amnesty can encourage "gestures of reconciliation which can contribute to reestablishing normal relations in the life of a nation which has been divided."18

\section{Achieving Peace-First in Practice}

There are a number of diplomatic tools available to pursue a peacefirst approach. These include limiting peace negotiation participants to those with the ability to actually end the violence (the guys with guns so to speak); accommodating and at times appeasing those interests, minimizing the role of justice mechanisms; and at times providing blanket amnesty.

\section{Singular Objective of Ending the Conflict}

To achieve peace, it is necessary to be singularly focused on ending the conflict. The focus of any agreement is a cessation of hostilities coupled with subsequent demobilization, demilitarization, and reintegration of combatants. ${ }^{19}$ Where necessary some sort of power sharing arrangement can be established to induce the parties to cease hostilities. ${ }^{20}$ The mandate and means for deploying peacekeepers or monitors is also a priority, and the establishment of some mechanisms to coordinate international assistance for reconstruction. The mediators and the parties must resist pressure to expand their mandate to include topics such as deep constitutional or electoral reform (beyond creating a framework or process

16. Revitalization in Peacebuilding, supra note 13 , at 4, 7-8.

17. Newman, supra note 14 , at 304 .

18. Treaties, States Parties and Commentaries, INT'L COMMITTEE RED CROSS, https://ihldatabases.icrc.org/applic/ihl/ihl.nsf/Comment.xsp?action=openDocument\&documentld=C6692EB184B 56F56C12563CD0043A476 (last visited Apr. 22, 2018) (discussing the purpose of Additional Protocol II's amnesty provision).

19. See Johannes Langer et al., Peace v. Justice: The Perceived and Real Contradictions of Conflict Resolution and Human Rights, in 8 CRITERIOS - CUADERNOS DE CIENCIAS JuRIDICAS Y POLÍTICA INTERNACIONAL 165, 167 (2015) (Colom.).

20. Id. 
for some future progress on these issues), the creation of new human rights bodies, and most certainly the establishment of complicated mechanisms for accountability. ${ }^{21}$ The mediators and the parties must avoid the temptation to be diverted or tempted to use the peace process to create a modern inclusive democratic state. ${ }^{22}$ That is the task of the parties-with assistance from the international community-only after the conflict has ended.

\section{Negotiating with the Guys with Guns}

To end a conflict, it is necessary to induce those actively engaged in the conflict to cease hostilities. It is not necessary to have the consent of civil society, refugees, internally displaced persons, marginalized populations, and women (unless they are armed actors). Including nonarmed actors distracts from the ability of the mediator to navigate the interests of the armed actors and creates space to introduce issues unrelated to bringing about an immediate end to the conflict. Only on the rarest occasions do armed combatants place accountability on the table as a key interest. Likely this is because anyone engaged in armed activity perceives that they may be brought before a tribunal; especially in light of the morally equivalent approach of seeking to "hold all sides accountable" even when one party is responsible for the overwhelming majority of atrocities. Only armed combatants should be at the negotiation table, and the mediator should engage exclusively with their interests.

\section{Accommodation and Appeasement}

Frequently it is necessary to accommodate or even appease the interests of the armed actors. While there is an emerging global consensus on issues such as democratic reform and the protection of human rights, these are seldom the objectives of all the major armed groups participating in the conflict. At times one of the armed groups is interested in promoting the demise of a repressive regime or defending a marginalized population from oppression. At other times the armed group is just interested in "their turn at the table" of corruption and repression.

There is always one major armed group - often the government-that is interested in retaining the status quo, and it is unlikely that the status quo is a democratic and human rights-respecting political structure. Frequently, it is in the interest of one or more of the armed groups to avoid accountability for any crimes that may have been committed by it or its

\footnotetext{
21. Id.

22. Id. at 177 .
} 
forces during the conflict. ${ }^{23}$ Given that nearly every conflict in the past few decades involved the commission of war crimes or crimes against humanity by at least one of the armed actors, there is little appetite for accountability. It is the job of the mediator to find a way to embrace the political reality and accommodate these less than ideal or altruistic interests to get the armed actors to cease the killing. ${ }^{24}$

\section{Minimizing Justice}

To accommodate or appease the armed actors it is often, if not always, necessary to minimize the creation of any mechanisms of justice that may be used to hold the armed actors accountable for war crimes. ${ }^{25}$ Who, after all, would sign an agreement that might bring an end to a conflict, only to find that he will be tried for war crimes, delegitimized in the eyes of his community, and incarcerated, preventing him from enjoying the fruits (legitimate or otherwise) of his armed actions?

In fact, recent statistical research indicates that for conflicts between 2002 and 2013, the involvement of the International Criminal Court (ICC) in a conflict significantly decreased the probability of reaching a timely end to the conflict. ${ }^{26}$ The author of this research points out that the pursuit of justice may undermine peace by "threatening leaders' political survival and personal freedom."27 Moreover, an armed party may also be incentivized to continue the conflict to make the gathering of evidence against them more difficult. ${ }^{28}$ Even justice-based mechanisms that are not prosecutorial, like truth commissions, should be avoided because they may also prolong negotiations and the conflict. The mediators must always remember that no matter how morally appealing it may be to create accountability for war crimes, assigning responsibility or punishing bad acts is not the purpose of the peace process - the only concern is ending the conflict. ${ }^{29}$

23. Id. at $170-71$.

24. See Langer et al., supra note 19 , at 170-71.

25. Id. at $\mathbf{1 7 0 .}$

26. Alyssa K. Prorok, The (In)compatibility of Peace and Justice? The International Criminal Court and Civil Conflict Termination, 71 INT'L ORG. 213, 214-15 (2017).

27. Id. at 215 .

28. Id. at 222 (prohibiting evidence gathering undermines investigators' ability to develop sufficient evidence to start a case).

29. See Human Rights in Peace Negotiations, supra note 2, at 256. 


\section{Amnesty}

In addition to minimizing the creation of accountability mechanisms, it may be necessary to simply agree upon a blanket or conditional amnesty. ${ }^{30}$ Because actors may be unwilling to step down from power or cease hostilities so long as they or their associates face the possibility of punishment, amnesties may be leveraged as a trade-off. ${ }^{31}$ In some instances there may be no alternative to granting amnesty as a precondition, so as to end the conflict more rapidly. ${ }^{32}$ While morally unappealing, so is the prospect of the further loss of life. Amnesty has been an integral part of numerous peace agreements, including Bougainville, ${ }^{33}$ Sierra Leone, ${ }^{34}$ South Africa, ${ }^{35}$ and Yemen. ${ }^{36}$

\section{Case Studies}

The peace-first approach has been tried and implemented in many conflicts. South Africa is often used as the archetype of success for the approach and the model of the benefits of prioritizing peace. ${ }^{37}$ In 1948, the white National Party became the governing party of South Africa. ${ }^{38}$ The party consolidated its power and instituted the statewide program of

30. Paul R. Williams \& Michael. P. Scharf, Peace with Justice?: War Crimes and ACCOUNTABILITY IN THE FORMER YUGOSLAVIA 29 (2002).

31. Darryl Robinson, Serving the Interests of Justice: Amnesties, Truth Commissions and the International Criminal Court, 14 EUR. J. INT'L L. 481, 495 (2003).

32. Minogue, supra note 14 , at 307.

33. Amnesty: Bougainville Peace Agreement, Art. 331, PEACE ACCORDS Matrix, https://peaceaccords.nd.edu/provision/amnesty-bougainville-peace-agreement (last visited Apr. 22, 2018) [hereinafter Bougainville Peace Agreement]; Amnesty: Lincoln Agreement, Art. 10, PEACE ACCORDS MATRIX, https://peaceaccords.nd.edu/provision/amnesty-bougainville-peace-agreement (last visited Apr. 22, 2018) [hereinafter Lincoln Agreement].

34. Amnesty: Lomé Peace Agreement, Art. $L X$, Peace Accords Matrix, https://peaceaccords.nd.edu/provision/amnesty-lom-peace-agreement (last visited Apr. 22, 2018).

35. S. AFR. (INTERIM) CONST., art. 251, 1993.

36. AMNESTY INT'L, YEMEN'S IMMUNITY LAW: BREACH OF INTERNATIONAL OBLIGATIONS 11 (2012), https:/www.amnesty.org/download/Documents/24000/mde310072012en.pdf; Yemen: Amnesty for Saleh and Aides Unlawful, HUM. RTS. WATCH (Jan. 23, 2012, 1:55 PM), https://www.hrw. org/news/2012/01/23/yemen-amnesty-saleh-and-aides-unlawful [hereinafter Yemen].

37. Elizabeth Sidiropoulos, South Africa's Regional Engagement for Peace and Security, FUNDACIÓN PARA LAS RELACIONES INTERNACIONALES Y EL DIÁLOGO EXTERIOR [FRIDE] [FOUNDATION FOR INTERNATIONAL RELATIONS AND FOREIGN Dialogue] 1, 7 (2007), http://fride.org/descarga/south.africa.comment.pdf.

38. Nigel Worden, The Making of Modern South Africa: Conquest, Apartheid, DEMOCRACY 102-04 (5th ed. 2012) (1994). 
apartheid, or racial segregation for the promotion of white interests. ${ }^{39}$ Political violence during the apartheid era led to approximately 75,000 people detained without trial, widespread torture, and 21,000 deaths, with 14,000 of these deaths occurring between 1990 to $1994 .{ }^{40}$

Negotiations between the all-white apartheid South African government and the anti-apartheid political parties, including the African National Congress (ANC), resulted in the 1993 interim constitution of South Africa, which formed the foundation for the first non-racial general elections in South Africa. ${ }^{41}$ The interim constitution included an amnesty clause providing that all persons and parties shall be granted amnesty for "acts, omissions and offences associated with political objectives and committed in the course of the conflicts of the past" through a mechanism determined by the newly elected Parliament. ${ }^{42}$ This provision laid the foundation for a mechanism to determine conditional amnesties. The express purpose of the amnesty was to advance national "reconciliation and reconstruction." ${ }^{43}$ Notably, key party negotiators, such as Dullah Omar, the ANC representative and future South African Minister of Justice, have confirmed that a peace agreement would not have been reached without the amnesty clause in the interim constitution. ${ }^{44}$

After elections, in 1995 the Parliament passed a law establishing the Truth and Reconciliation Commission. ${ }^{45}$ The Truth Commission was designed to give effect to the amnesty clause in the constitution by granting amnesty to all persons who made a "full disclosure of all the relevant facts relating to acts associated with a political objective committed in the

39. See LeONARD ThOMPSON, A History OF SOUTH AFrica 187-90 (3d ed. 2001) (recounting the institutionalization of the apartheid era in South Africa by the National Party through consolidation of resources and legislative activities); see also RODNEY DAVENPORT \& CHRISTOPHER SAUNDERS, SOUTH AFRICA: A MODERN HISTORY 379-83 (5th ed. 2000) (describing the National Party's dominance in government and removal of the coloured vote to prevent any dilution of this power).

40. Human Rights Comm. of S. Afr., A Crime Against Humanity: Analysing the REPRESSION OF THE APARTHEId STATE (Max Coleman ed., 1998).

41. See S. AFR. (INTERIM) CONST. art. 251, 1993; see Paul Lansing \& Julie C. King, South Africa's Truth and Reconciliation Commission: The Conflict Between Individual Justice and National Healing in the Post-Apartheid Age, 15 ARIZ. J. INT'L \& COMP. L. 753, 757-58 (1998) (enumerating the specific voting changes made by the 1993 Constitution that would allow for the first multi-racial election in South African history).

42. S. AFR. (INTERIM) CONST. art. 251, 1993.

43. Id.

44. Lyn S. Graybill, Truth \& ReConciliation in South Africa: Miracle or Model? 59 (2002).

45. Id. 
course" of apartheid ${ }^{46}$ While not without controversy, most commentators consider the amnesty-based peace process to have been successful in bringing an end to the South African conflict and laying the foundation for a lasting peace. ${ }^{47}$

Another conflict where a peace-first approach prevailed during the peace process was the Bougainville civil war, fought between the government of Papua New Guinea and the region of Bougainville. ${ }^{48}$ In this case the parties agreed upon an unconditional blanket amnesty. ${ }^{49}$ The brutal civil war between the government of Papua New Guinea and the Bougainville Revolutionary Army lasted nearly a decade and resulted in the deaths of 15,000 to 20,000 civilians and fighters - ten percent of the Bougainville population. ${ }^{50}$ The conflict was characterized by war crimes and atrocities, including razing villages and attacks on civilians by the government, and rape and torture by both parties. ${ }^{51}$ The peace agreements, which rendered a plan for Bougainville to become an autonomous entity with the right to eventual hold an independence referendum, included a provision that granted "amnesty and pardon" to all persons involved in crisis-related activities or convicted of offenses arising out of crisis-related activities. ${ }^{52}$ Despite a relative failure to fully implement the peace agreement, the amnesty is generally considered to have successfully moved Bougainville into a period of lasting peace. ${ }^{53}$

The ongoing conflict in Yemen has also seen attempts to resolve the conflict using a peace-first approach. The conflict began in 2011 when, caught up in the momentum of the Arab Spring, Yemeni students rose up demanding social change. ${ }^{54}$ What started as a peaceful protest demanding improved living conditions and jobs turned violent when government

46. Promotion of National United and Reconciliation Act 34 of 1995 (2005), http://www. justice.gov.za/legislation/acts/1995-034.pdf (S. Afr.).

47. See, e.g., Charles P. Trumbull IV, Giving Amnesties A Second Chance, 25 BERKLEY J. INT'L L. 283, 293, 295, 314 (2007).

48. Peter Reddy, Reconciliation in Bougainville: Civil War, Peacekeeping and Restorative Justice, 11 CONTEMP. J. REv. 117, 117-19 (2008).

49. See id. at 117.

50. Id. at 117,119

51. Id.

52. Bougainville Peace Agreement, supra note 33; Lincoln Agreement, supra note 33.

53. Reddy, supra note 48, at 119.

54. See Khaled Fattah, Yemen: A Social Intifada in A Republic of Sheikhs, 18 Midde E. POL'Y 79, 81 (2011) (describing the 2011 "Youth-led Revolt" in Yemen and what factors contributed to the societal unrest within the country); see also Sheila Carapico, Yemen Between Revolution and Counter-Terrorism, in WHY YEMEN MATTERS: A SOCIETY IN TRANSITION 29, 30 (Helen Lackner ed., 2014) (depicting instances of cultural transformation, including women's participation in protests, blossoming during the Yemen Revolution). 
security forces killed fifty-two protestors. ${ }^{55}$ This event fractured the government with many generals, ambassadors, and government leaders defecting. ${ }^{56}$ Government security forces targeted and killed antigovernment organizers, summarily executing demonstrators, arbitrarily detaining persons of interest, performing acts of torture, and treating civilians to cruel, inhuman, or degrading treatment. ${ }^{57}$ Within a year, over 2000 people had been killed and more than 22,000 injured. ${ }^{58}$

With the conflict turning in the favor of the opposition, the Gulf Cooperation Council stepped in to negotiate an end to hostilities and a transfer of power agreement. ${ }^{59}$ The peace agreement brokered by the Gulf Cooperation Council and approved by the U.N. approved peace deal, provided immunity for Yemeni President Ali Abdullah Saleh and his aides. ${ }^{60}$ The agreement-President Saleh signed in November 2011 and the sitting Yemeni Parliament passed granted immunity to Saleh from prosecution for any crimes during his thirty-three-year tenure. ${ }^{61}$ Specifically, the peace agreement provided that President Ali Abdullah Saleh was entitled to "complete immunity from legal and judicial prosecution" for any acts that occurred during his presidency and until the date the law was passed. ${ }^{62}$ The agreement also shielded from prosecution those who served under Saleh, by providing that immunity is granted to

55. Fattah, supra note 54, at 81-82. But see Mohammad Farazmand, The Nature of 2011 Arab Uprisings: A Comparative Analysis, 2 IRANIAN REV. FOREIGN AFF. 7, 15 (2011) (marveling at the unexpected phenomenon of a divided Yemen unifying under the singular demand to remove President Saleh and remaining peaceful in the face of government violence).

56. See, e.g., Carapico, supra note 54, at 34-35 (listing the different categories of individuals who resigned in outrage of the March 18 sniper attack).

57. E.g. U.N. High Commissioner for Human Rights, Report on the Visit by the Office of the High Commissioner for Human Rights to Yemen, 10 32-43 U.N. Doc. A/HRC/18/21 (Sept. 16, 2011).

58. Ahmed al-Haj, Yemen Says More Than 2,000 Killed in Uprising, WasH. Post (Mar. 18, 2012), https:/www.washingtonpost.com/world/middle_east/yemen-says-more-than-2000-killed-in-upris ing/2012/03/18/gIQAGOtcLS_story.html?utm_term=.6c8b804b3184; see generally Chris Baker Evens et al., Yemenis Oust Saleh Regime (Yemen Revolution), 2011-2012, GLOBAL NONVIOLENT ACTION DATABASE (Aug. 28, 2012), https://nvdatabase.swarthmore.edu/content/yemenis-oust-saleh-regimeyem en-revolution-2011-2012 (summarizing the different protests and events that resulted in the death of Yemenis during the year of the Yemen Revolution).

59. See Wojciech Grabowski, The Role of the Gulf Cooperation Council (GCC) in The (De)Stabilization of Yemen, in ARAB AND MUSLIM WORLD IN INTERNATIONAL RELATIONS 127, 131-35 (Rafał Ożarowski \& Wojciech Grabowski eds., 2016) (reviewing the elements of the GCC's power transfer proposal and its failure to resolve the issues at the heart of the Revolution).

60. Yemen, supra note 36 .

61. Id.

62. Law No. (1) of 2012, Granting Immunity from Legal and Judicial Prosecution arts. 1, 5 (Yemen). 
"officials who have worked under the President — in state civil, military and security agencies - in connection to politically motivated acts carried out during the course of their official duties[.] ${ }^{163}$ In exchange, Saleh was to leave office within thirty days, transferring power to his Vice President. ${ }^{64}$ Yemen is in the midst of a brutal civil war, and until recently it was President Saleh who co-led a coalition rebelling against the government installed by the peace agreement. ${ }^{65}$ There is nearly unanimous agreement among commentators that the amnesty played a key role in permitting the former President to retain his political influence and plot a return to power through civil war. ${ }^{66}$

\section{THE “JUSTICE-FIRST” APPROACH \\ "If you want peace, work for justice." Pope Paul VI ${ }^{67}$}

The justice-first approach will be explored in a similar format to the previous section on the peace-first approach. First, the tenants of the justice-first approach and the primary categories of practitioners that support it will be identified. Next, the section will explore the advantages of taking a justice-first approach in peace processes. The section will then focus on actions that can be taken to implement the justice-first approach in the peace process. Finally, the section will examine the case studies of Yugoslavia, Rwanda, Uganda and Sudan.

\section{A. Prioritizing Accountability}

The "justice-first" approach advances the notion that accountability through prosecution must be an integral aspect of any negotiated agreement or post-conflict plan.$^{68}$ While the justice-first approach does seek peace, the approach supports the idea that quick peace should not come at the cost of the pursuit of justice. ${ }^{69}$ While peace may be achieved temporarily through a peace-first approach, durable, long-term peace cannot be achieved without justice. Although insisting upon accountability mechanisms may prolong

63. Id. art. 2 .

64. Yemen's Saleh Agreed to Transfer Power, AL JAZEera (Nov. 24, 2011), http://aljazeera. com/news/middleeast/2011/11/2011112355040101606.html.

65. See id.

66. See id.

67. Pope Paul IV, Homily on World Peace Day (Jan. 1, 1972).

68. Scharf \& Williams, supra note 10 , at 170 .

69. See id. 
the conflict, the eventual peace that is created is more likely to be sustainable. The justice-first approach is willing to cope with a longer conflict in order to achieve a sustainable peace.

The justice-first approach has garnered much support. Victims frequently demand a retributive approach towards perpetrators due to the grave nature of human rights violations. ${ }^{70}$ Parties to a conflict who have disproportionately suffered crimes at the hand of the opposing party generally support the justice-first approach, as do individual victims. ${ }^{71}$ Additionally, many states, particularly those who helped found the ICC and who have ratified the Rome Statute, tend to promote a justice-first approach to peacemaking. ${ }^{72}$ Countless international non-government organizations (NGOs) are dedicated to promoting justice for crimes committed and to preparing for future prosecutions or other justice mechanisms, and even more NGOs not directly involved have taken a firm stance that justice should be an inextricable part of peacemaking. ${ }^{73}$

\section{B. Benefits of the Justice-First Approach}

With the formalization of international laws on war crimes, crimes against humanity, and other atrocities as well as the establishment of prosecutorial mechanisms to hold perpetrators accountable, the justice-first approach recognizes that this progress is meaningless if justice is waived. Furthermore, the justice-first approach asserts that the implementation of justice mechanisms assists in creating stable peaceful societies in postconflict states. Justice mechanisms promote this by establishing individual responsibility and denying collective guilt, delegitimizing institutions and war criminals responsible for the commission of atrocities, establishing an accurate historical record, providing victim catharsis, and promoting deterrence. ${ }^{74}$

70. Chandra lekha Sriram, Confronting Past human Rights Violations: Justice vS. Peace In Times of TRAnsition 6-7 (2004); see also Reddy, supra note 48, at 119.

71. See SRIRAM, supra note 70, at 6-7.

72. See Catherine Gegout, The International Criminal Court: Limits, Potential and Conditions for the Promotion of Justice and Peace, 34 THIRD WORLD Q. 800, 800 (2013).

73. See Juliane Kippenberg \& Pascal Kambale, human Rights watch, The INTERNATIONAL CRIMINAL COURT: How NONGOVERNMENTAL ORGanizations CAN CONTRIBUTE To the Prosecution of War Criminals 14-18 (Alison Des Forges \& Richard Dicker eds., 2004), https://www.hrw.org/legacy/backgrounder/africa/icc0904/icc0904.pdf.

74. Scharf \& Williams, supra note 10 , at 170. 


\section{Denying Collective Guilt}

If justice is not pursued, guilt may be assigned to an entire population rather than the individuals responsible for the crimes. ${ }^{75}$ Additionally, because justice mechanisms attach responsibility to specific persons, they lessen the risk that victims and third parties will view an entire group or population as to blame for the harm. ${ }^{76}$ By avoiding a perception of collective guilt, a post-conflict society may reconcile and heal.

\section{Delegitimizing Institutions and War Criminals}

Justice mechanisms delegitimize institutions and leaders responsible for the commission of atrocities. Justice can advance a sustainable end to conflict by punishing perpetrators and removing wrongdoers from leadership and delegitimizing their ideology. ${ }^{77}$ Furthermore, justice mechanisms identify the institutions responsible for crimes and helps provide a basis for dismantling them. ${ }^{78}$

\section{Establishing an Accurate Historical Record}

Justice mechanisms can establish an accurate historical record of the conflict, which contributes to long-term peace. The "collective historical record" that prosecutions produce provides legitimacy to the new postconflict government while delegitimizing the former regime. ${ }^{79}$ Such a record also allows societies to learn from the past, have a mutual understanding of the actions of all parties, and move towards communal reconciliation based on a shared understanding of the truth. ${ }^{80}$

\section{Facilitating Victim Catharsis}

Holding violators accountable through justice mechanisms facilitates victim catharsis. Enduring peace requires justice and accountability because when the underlying cause of a conflict goes unaddressed and

75. Id.

76. Id. at 171 .

77. See Laurel E. Fletcher, $A$ Wolf in Sheep's Clothing? Transitional Justice and Effacement of State Accountability for International Crimes, 39 FORDHAM INT'L L.J. 447, 450 (2016); Scharf \& Williams, supra note 10 , at 170.

78. Richard J. Goldstone, Justice as A Tool for Peace-Making: Truth Commissions and International Criminal Tribunals, 28 N.Y.U. J. INT'L L. \& POL. 485, 490 (1996).

79. Ruti G. Teitel, Globalzing TranstTional Justice: Contemporary Essays 105 (2014) (finding that historical accounts provide states with self-knowledge shining a light of past offenses and abolishing these abuses in the new societal order).

80. See Scharf \& Williams, supra note 10, at 174-75. 
victims do not receive redress, the risk of returning to conflict remains high. ${ }^{81}$ This is particularly true when perpetrators of violence or human rights abuses are granted amnesty and therefore escape punishment. In the absence of formal justice the victims and other individuals who feel wronged may engage in extrajudicial means to achieve justice, including violence. $^{82}$ Through trials, victims are also able to recover - or establishdignity as the possessors of legal rights, which, in turn, come with legal remedies. ${ }^{83}$ In recognizing victims and providing them legally ordered restitution, prosecutions also provide a venue for victims to heal. ${ }^{84}$

\section{Deterrence}

Accountability also promotes long-term peace by deterring future atrocities. ${ }^{85}$ Post-conflict trials remove and punish leaders who perpetrated gross violations, preventing such individuals from committing further violations. ${ }^{86}$ Conversely, if persons, particularly leaders, are not held responsible, they may feel emboldened by their impunity and be more likely to interfere with the peace-building process or commit future crimes. ${ }^{87}$ The incorporation of justice mechanism "are a foundational and forward-looking affirmation that no group, including public officials and the armed forces, is above the law and that the new democracy will not tolerate such behavior." ${ }^{988}$ The implementation of justice mechanisms can reinforce broader security and justice reforms to support the post-conflict state's ability to strengthen rule of law and establish a framework for sustainable peace. ${ }^{89}$ In this way, the justice-first approach believes future

81. Peace Versus Justice: A False Dilemma, ICTJ (May 9, 2011), https://www.ictj.org/news/ peace-versus-justice-false-dilemma.

82. Tove Grete lie et al., Post-Conflict Transitions Working Paper No. 5: PostConflict Justice and Sustainable Peace, World Bank Policy Research Working Paper 5 (2007).

83. Reed Brody, Justice: The First Castalty of Truth?, NATION (Apr. 12, 2001), https://www. thenation.com/article/justice-first-casualty-truth (concluding that the immunity from justice that a small group of elites in Haiti received which allowed them to get away with murder and plunder for generations left the majority of poorer citizens with the impression they had not rights)

84. Antoine Hol, The Theatre of Justice: On the Educational Meaning of Criminal Trials, in TRANSITIONAL JUSTICE: IMAGES AND MEMORIES 71, 83-84 (Chrisje Brants et al. eds., 2013).

85. Prorok, supra note 26, at 214.

86. LIE ET AL., supra note 82, at 5.

87. Scharf \& Williams, supra note 10 , at 171 .

88. Brody, supra note 83. But see RuTI G. TEITEL, Transitional JustiCE 11 (2000) (arguing that trials are backward-looking at the same time).

89. U.N. Secretary-General, Guidance Note by the Secretary-General: United Nations Approach to Transitional Justice (Mar. 2010), https://www.un.org/ruleoflaw/files/TJ_Guidance_Note 
crimes can be deterred by demonstrating that such crimes will be punished, developing the institutions capable of punishing any future crimes, and establishing a strong framework for rule of law.

\section{Achieving Justice-First in Practice}

To implement a justice-first approach to peace, it is necessary to ensure that an accountability mechanism exercises jurisdiction over those who may be responsible for the commission of atrocities. The mechanism may be an existing court or tribunal, or it could be one created for the particular conflict by the Security Council, created by the U.N. in agreement with the state and endorsed by the General Assembly, or by the parties to the peace process. ${ }^{90}$ The mechanism may also be active during the peace process, or it may come into force after the process, but with no retroactive jurisdiction. ${ }^{91}$

Peace processes are more likely to confer jurisdiction to an accountability mechanism when the peace process is inclusive of the interests of all key stakeholders, not just the armed combatants. While the armed actors are less likely to seek the inclusion of an accountability mechanism, civil society, victims, marginalized populations, and other groups who were harmed during the conflict and did not, themselves, commit atrocities are likely to seek justice. A transparent peace process is more accessible to these stakeholders and makes it more likely that they will be able to assert their interests for insertion in the peace agreement. Accountability mechanisms are most likely to be fair, balanced, and successful in states that emerge from conflict as democracies. The peace process itself should model the democratic process and inclusive representation that is hoped to be achieved in the state.

There are a number of justice-based mechanisms that can be employed to further the justice-first approach. These include referral to the ICC; the creation of an ad hoc tribunal; the establishment of hybrid tribunals; the creation of domestic war crimes chambers, the application of universal jurisdiction, and the avoidance of amnesty. Notably, the parties can

\footnotetext{
_March_2010FINAL_pdf; Padraig McAuliffe, Transitional Justice's Impact on Rule of Law: Symbol or Substance?, in RESEARCH HANDBOOK ON TRANSITIONAL JustiCE 74, 90 (Cheryl Lawther et al. eds., 2017) (questioning whether capacity-building and rule of law are realistic objectives due to the selectivity of prosecutions and the complexity of dealing with past crimes, which could blur the line between rule of law and political judgment).
}

90. See generally Rome Statute of the International Criminal Courts: Some Questions and Answers, U.N. DEP'T PUB. INFO. (Oct. 1998), http://legal.un.org/icc/statute/iccq\&a.htm [hereinafter Rome Statute: Q\&A].

91. See id. 
activate some of these mechanisms, while others are activated by the international community.

\section{The International Criminal Court}

The ICC can prosecute crimes of genocide, crimes against humanity, and war crimes. ${ }^{92}$ The ICC can exercise jurisdiction over atrocities if: (1) the atrocities were committed by or on the territory of states that have subjected themselves to the jurisdiction of the court, (2) the U.N. Security Council refers the matter to the court, or (3) the state refers the matter to the court. ${ }^{93}$ The court also has jurisdiction over nationals of state parties to the Rome Statute, regardless of where the individual's acts took place. ${ }^{94}$

States that are parties to the Rome Statue may find the court exercising jurisdiction and indicting key players in the midst of the peace process or shortly thereafter. The ICC has ongoing investigations and cases involving, Burundi, Georgia, the Côte d'Ivoire, and Kenya, which were initiated by the ICC itself. ${ }^{95}$ The ICC also unilaterally initiated preliminary examinations in Afghanistan, Colombia, Guinea, Nigeria, Ukraine, and in Iraq. ${ }^{96}$

During a peace process, the U.N. Security Council acting under Chapter VII of the U.N. Charter, may determine that the conflict presents a threat to international peace and security and confer jurisdiction on the ICC. ${ }^{97}$ The Security Council made such referrals in the case of Sudan (Darfur) $^{98}$ and Libya. ${ }^{99}$ In the case of Sudan, the court indicted Omar AlBashir, the President of Sudan for genocide, ${ }^{100}$ and in the case of Libya the court indicted Muammar Gaddafi for crimes against humanity. ${ }^{101}$
92. Id.
93. Id.
94. Id.

95. Situations Under Investigation, INT'L CRIM. CT., https:/www.icccpi.int/pages/situations .aspx (last visited Apr. 22, 2018)

96. Preliminary Examinations, INT'L CRIM. CT., https://www.icc-cpi.int/pages/preliminaryexaminations.aspx (last visited Apr. 22, 2018).

97. U.N. Charter ch. VII

98. S.C. Res. 1593, I 1 (Mar. 31, 2015); Bethel Aregawi, The Politicisation of the International Criminal Court by United Nations Security Council Referrals, ACCORD (July 21, 2017), http://www.accord.org.za/conflict-trends/politicisation-international-criminal-court-united-nationssecuri ty-council-referrals/ (S. Afr.).

99. S.C. Res. 1970, I 4 (Feb. 26, 2011 ); Aregawi, supra note 98.

100. Prosecutor v. Al Bashir, ICC-02/05-01/09, Case Information Sheet, (Apr. 6, 2017), https://www.icc-cpi.int/darfur/albashir/Documents/AlBashirEng.pdf.

101. Prosecutor v. Gaddafi, ICC-01/11-13, Warrant of Arrest, (June 27, 2011), https://www.icc-cpi.int/CourtRecords/CR2011_08351.pdf. 
States may also refer matters to the ICC on their own initiative, as was the case with the Central African Republic, the Democratic Republic of the Congo (DRC), Uganda, and Mali. ${ }^{102}$ These states all referred the matter to the court while the conflict was still ongoing and arrest warrants, indictments, or convictions were issued against political and armed leaders during the peace process or directly after. ${ }^{103}$ For instance, in the DRC, Thomas Lubanga Dyilo founded and led the rebel group, the Union of Congolese Patriots, and was a key actor in the Ituri Conflict. ${ }^{104}$ The ICC issued a warrant for Lubanga's arrest while the peace process was underway, and Lubanga was arrested and indicted. ${ }^{105}$ The ICC also opened preliminary examinations in Gabon and Palestine at the request of the states. ${ }^{106}$ Such a referral may happen during a conflict, retroactively by a new government, or by including a commitment to refer in the terms of a peace agreement. ${ }^{107}$

\section{Ad Hoc Tribunals}

On a number of occasions the Security Council, or the General Assembly acting with a member state, created an ad hoc tribunal to cement a role for justice in the peace process or as part of the transition process. ${ }^{108}$ Such tribunals were created for the former Yugoslavia and Rwanda. ${ }^{109}$ The Yugoslavia Tribunal was formed and began its investigations and indictments while the peace process was ongoing, and the Rwanda Tribunal was established at the conclusion of the conflict. ${ }^{110}$

102. Situations Under Investigation, supra note 95.

103. Gegout, supra note 72 , at 810 ; see generally SARA DAREHSHORI, HUMAN RIGHTS Watch, Selling Justice Short: Why Accountability Matters for Peace (Richard Dicker et al. eds., 2009), https://www.hrw.org/report/2009/07/07/selling-justice-short/why-accountability-matterspea ce.

104. A Duty to Protect: Justice for Child Soldiers in the D.R.C., WITNESS \& AMNESTY INT'L 18, https://www.amnestyusa.org/files/pdfs/dtplessonguide.pdf (last visited Apr. 22, 2018) [hereinafter $A$ Duty to Protect].

105. Prosecutor v. Lubanga Dyilo, ICC-01/04-01/06, Warrant of Arrest, (Feb. 10, 2006), https://www.icc-cpi.int/CourtRecords/CR2006_02234.pdf; Pursuing Peace, Justice or Both?, INT'L CTR. FOR TRANSITIONAL JUST. 2 (2009), https://www.ictj.org/sites/default/files/ICTJ-Global-PeaceJustice-2009-English.pdf [hereinafter Pursuing Peace].

106. Preliminary Examinations, supra note 96.

107. A Duty to Protect, supra note 104.

108. OfFice of the Prosecutor, InT'L Criminal Court, Report on Preliminary EXAMINATION ACTIVITIES (2015) ๆ 9 (2015), https://www.icc-cpi.int/iccdocs/otp/OTP-PE-rep-2015Eng.pdf; Rome Statute: Q\&A, supra note 90.

109. Rome Statute: Q\&A, supra note 90

110. Id. 


\section{Hybrid Tribunals}

Hybrid tribunals are a mix of international and domestic actors and can be created by the international community, the parties themselves, or in collaboration. ${ }^{111}$ The U.N. Security Council, at the request of the government of Sierra Leone, created the Special Court for Sierra Leone, ${ }^{112}$ and the General Assembly in cooperation with Cambodia created the Extraordinary Chambers in the Courts of Cambodia ("Cambodia Tribunal"). ${ }^{113}$ The Sierra Leone Tribunal conducted prosecutions based on both international and domestic law for crimes committed during the Sierra Leone Civil War, which began with a Liberian-led coup attempt. ${ }^{114}$ The tribunal tried and convicted a number of high-level officials, including Liberian President Charles Taylor. ${ }^{115}$ The Cambodia Tribunal was created in 2001 to try cases based on international and domestic law for acts occurring under the Khmer Rouge from 1975 to $1979 .{ }^{116}$ To date, the tribunal has indicted five high-level Khmer Rouge officials, leading to three convictions ${ }^{117}$ and two suspensions of proceedings — one due to the death of the defendant ${ }^{118}$ and one due to the defendant's poor health. ${ }^{119}$

111. Caitlin E. Carroll, Hybrid Tribunals Are the Most Effective Structure for Adjudicating International Crimes Occurring Within A Domestic State 1 (Seton Hall L. Student Scholarship Paper No. 90, 2013), http://scholarship.shu.edu/cgi/viewcontent.cgi?article $=1090 \&$ context=student_scholarsh ip; OFFICE OF THE U.N. HIGH COMM'N FOR HUMAN RIGHTS, RULE-OF-LAW TOOLS FOR POST-CONFLICT STATES, at 13-14, U.N. Sales No. E.08.XIV.2 (2008).

112. S.C. Res. 1315, 1 (Aug. 14, 2000); TOM PERRIEllo \& MARIEKE WIERDA, INT'L CENTER for Transitional Justice, The SPEClal Court for Sierra Leone Under SCrutiny 1 (2006), http:/hrlibrary.umn.edu/instree/SCSL/Case-studies-ICTJ.pdf.

113. U.N. Audiovisual Library of Int'l Law, Agreement between the UN and the Royal Government of Cambodia Concerning the Prosecution Under Cambodian Law of Crimes Committed During the Period of Democratic Kampuchea, at 1 (2012), http://egal.un.org/avl/pdf/ha/abunac/ abunac_ph_e.pdf.

114. PERRIEllo \& WIERDA, supra note 112, at 2,4, 44; Sierra Leone Profile: Timeline, BBC NEws (Apr. 5, 2018), http://www.bbc.com/news/world-africa-14094419 [hereinafter BBC NEws].

115. PERRIELlo \& WIERDA, supra note 112, at 27; BBC NeWS, supra note 114.

116. Nushin Sarkarati et al., Int'L Fed'N Human Rights, The Extraordinary Chambers IN THE COURTS OF CAMBODIA (ECCC) 3 (Antoine Bernard ed., 2011), http://www.fidh.org /IMG/pdf/dpcambodgedec2011_final.pdf.

117. Chun Han Wong, Khmer Rouge Leaders Convicted of Crimes Against Humanity, WALL ST. J., https://www.wsj.com/articles/khmer-rouge-leaders-convicted-of-crimes-against-humanity-14073 1407383717 (last updated Aug. 7, 2014).

118. leng Sary (Former Accused), EXTRAORDINARY ChAMBERS CTS. OF CAMBOdia, https:// www.eccc.gov.kh/en/indicted-person/ieng-sary-fomer-accused (last visited Apr. 22, 2018).

119. Associated Press in Phnom Phen, Cambodia's War Crimes Tribunal Releases Former Khmer Rouge Leader, GUARDIAN (Sept. 16, 2012, 11:20), https://www.theguardian.com/world/2012 /sep/16/khmer-roughe-leader-released. 


\section{Domestic Tribunals}

Domestic courts and tribunals may also be utilized to prosecute atrocities and can be written directly into the peace agreement. Pre-existing state courts can be used, especially if the state has strong legal institutions and the courts have jurisdiction over atrocities. Alternatively, a new domestic tribunal specifically focused on prosecuting atrocities that occurred during the conflict can be created. In Uganda, the International Crimes Division (ICD), a special division in the High Court of Uganda, was established in accordance with the comprehensive peace agreement between the government and the Lord's Resistance Army (LRA), a rebel group. ${ }^{120}$ The ICD's prosecutorial efforts are complementary to the ICC's ongoing LRA prosecutions. ${ }^{121}$ In Colombia, under the 2016 peace agreement between the government and the Revolutionary Armed Forced of Columbia (FARC), FARC members who provide false testimony, fail to make an honest confession, or refuse to confess at all to the truth commission can be prosecuted in the Colombia criminal justice system. ${ }^{122}$

\section{Universal Jurisdiction}

Universal jurisdiction is the "assertion of jurisdiction over offences regardless of the place where they were committed and the nationality of the perpetrator or the victim." 123 The basis of universal jurisdiction is found in both the Geneva Conventions and customary international law. ${ }^{124}$ A state may exercise universal jurisdiction by enacting state-level universal jurisdiction legislation and then proceeding with investigations and trials, or by the state courts assert international law, rather than state law. ${ }^{125}$ One of the first instances of states exercising universal jurisdiction were the

120. Kirsty McNamara, Seeking Justice in Ugandan Courts: Amnesty and the Case of Thomas Kwoyelo, 12 Wash. U. Global StUd. L. REV. 653, 653 (2013).

121. International Crimes Division, JUDICIARY: REPUBLIC UGANDA, http://www.judiciary. go.ug/data/smenu/18/International\%20Crimes\%20Division.html (last visited Apr. 22, 2018) [hereinafter UGANDA JUDICIARY].

122. Nicolás Carrillo-Santarelli, An Assessment of the Colombian-FARC 'Peace Jurisdiction' Agreement, EJL: TALK!: BLOG EUR. J. INT'L L. (Sept. 29, 2015), https://www.ejiltalk.org/anassess ment-of-the-colombian-farc-peace-jurisdiction-agreement/.

123. Universal Jurisdiction Over War Crimes, ICRC (Mar. 2014), https://www.icrc.org/eng/ assets/files/2014/universal-jurisdiction-icrc-eng.pdf.

124. Id. Under the four Geneva Conventions of 1949, "[s]tates are required to search for alleged offenders 'regardless of their nationality,' and either bring them before their own courts or hand them over for trial by another State Party which has made out a prima facie case." Id. While customary international law supports a state's right to exercise universal jurisdiction, it does not require states to exercise it. Id.

125. Id. 
prosecutions of former Chilean dictator, Augusto Pinochet in courts in both Spain and England. ${ }^{126}$ Ultimately, both Spanish and British courts made their decisions grounded in universal jurisdiction as codified in their domestic laws, ${ }^{127}$ and these cases set off a firestorm, bringing universal jurisdiction front and center in efforts to hold violators accountable for war crimes and crimes against humanity. ${ }^{128}$

126. See Patrick Wegner, No Limits for Justice? Universal Jurisdiction and the Case of Former Chadian President Hissene Habré, Just. ConfLICT (Dec. 18, 2011), https://justiceinconflict.org/2011/ 12/18/no-limits-for-justice-universal-jurisdiction-and-the-case-of-former-chadian-president-hissenehabr e/ (naming Pinochet's case "the most famous" to be brought under universal jurisdiction); Universal Jurisdiction, INT'L JUST. RESOURCE CTR., http://www.ijrcenter.org/cases-before-nationalcourts/dome stic-exercise-of-universal-jurisdiction (last visited Apr. 22, 2018) (including Pinochet's case on its list of "Prominent Cases Involving Universal Jurisdiction"); see generally Inbal Sansani, The Pinochet Precedent in Africa: Prosecution of Hissène Habré, 8 HUM. RTS. BRIEF 32 (2001) (reviewing the application of universal jurisdiction in the case of Pinochet); Sofie A. E. Høgestøl, The Habré Judgement at the Extraordinary African Chambers: A Singular Victory in the Fight Against Impunity, 34 NORDIC J. HUM. RTs. 147, 148-49 (2016) (discussing the seesaw between the Spanish and English courts on what legal standards to apply to Pinochet's case). For more on the efforts of the Spanish court to prosecute Augusto Pinochet, see generally Naomi Roht-Arriaza, The Pinochet Precedent and Universal Jurisdiction, 35 NEW ENG. L. REv. 311 (2011).

127. See Sansani, supra note 126, at 33 (finding both the Spanish and English courts grounded their jurisdiction decisions in domestic law that codified universal jurisdiction over certain activities). In Spain, Article 23 of the Organic Law of the Judicial Power grants Spanish courts jurisdiction over crimes that can be classified as torture, genocide, crimes against humanity, or other crimes in contravention of international agreements. MARGARITA LACABE, THE CRIMINAL ProceduRES AGAINST CHILEAN AND ARGENTINEAN REPRESSORS IN SPAIN: A SHORT SUMMARY (1998), http://www. derechos.net/marga/papers/spain.html. Under this law, the Spanish court claimed jurisdiction over Pinochet since the complaint alleged genocide, terrorism, and crimes against humanity. Id. Similarly, England had ratified the Torture Convention and subsequently incorporated that international agreement into its domestic law allowing universal jurisdiction over cases of torture. Tanaz Moghadam, Note, Revitalizing Universal Jurisdiction: Lessons from Hybrid Tribunals Applied to the Case of Hissène Habré, 39 Colum. Hum. RTS. L. REv. 471, 480 (2008). This being the case, U.K. courts had jurisdiction over Pinochet and could extradite him to Spain based on his conviction for torture. Id. at 481.

128. See Paul Chevigny, The Limitations of Universal Jurisdiction, Global POL'Y F. (Mar. 2006), https://www.globalpolicy.org/component/content/article/97/32133.html (recognizing the Pinochet case as the start of the "high tide" of universal jurisdiction cases); see also Ex-Chad Dictator Indicted in Senegal, HUM. RTS. WATCH (Feb. 3, 2000, 7:00 PM), https://www.hrw.org/news/2000/0 2/03/ex-chad-dictator-indicted-senegal (viewing the Pinochet case as reaffirming the principles of universal jurisdiction wherein states can judge crimes against humanity no matter where the acts occurred and can extend this jurisdiction even to former heads of state). 


\section{Barring Amnesty}

Many scholars argue that amnesty for crimes against humanity, war crimes, and genocide is in and of itself a violation of international law. ${ }^{129}$ The U.N. has also established guidelines that prohibit its representatives from supporting amnesty provisions. ${ }^{130}$ Indeed, the international community tends to hold that perpetrators of war crimes and human rights violations should be held accountable. ${ }^{131}$ Moreover, some argue that customary international law also obligates states to bring perpetrators of international crimes to justice. ${ }^{132}$ Parties may be legally obligated to pursue justice mechanisms as a part of the peace process.

In some states, there is a combination of the above-mentioned accountability mechanisms. For instance, in Bosnia, the ad hoc Yugoslavia Tribunal was initiated during the conflict and later, after the peace agreement, domestic prosecutions began as well. ${ }^{133}$ In Rwanda, the ad hoc Rwandan Tribunal functioned simultaneously with domestic prosecutions. ${ }^{134}$ Additionally, in Rwanda, the gacaca courts, traditional justice system, provided community-level truth and reconciliation. ${ }^{135}$ In Colombia, the ICC has begun preliminary investigations in parallel to the domestic prosecutorial process. ${ }^{136}$

129. Pursuing Peace, supra note 105 , at 1 .

130. William A. Schabas, National Amnesties, Truth Commissions and International Criminal Tribunals, in RESEARCH HANDBOOK ON INTERNATIONAL CRIMINAL LAW 373, 374 (Bartram S. Brown ed., 1st ed., 2011). However, Article 6(4) of the International Covenant on Civil and Political Rights (ICCPR) and Article 6(5) of Additional Protocol II both include references to the right of a person to be pardoned or receive amnesty. Id. at 375 . One caveat is that the context in which both are written seems to refer to cases of capital punishment, not post-conflict situations. Id.

131. See LIE ET AL., supra note 82 , at 1.

132. Id.

133. What Is the Former Yugoslavia?, U.N. INT'L CRIMINAL TRIBUNAL FOR FORMER YUGOSLAVIA, http://www.icty.org/en/about/what-former-yugoslavia (last visited Apr. 22, 2018) [hereinafter ICTY].

134. Rwanda: International Tribunal Closing Its Doors, HUM. RTS. WATCH (Dec. 23, 2015, 2:50 AM), https://www.hrw.org/news/2015/12/23/rwanda-international-tribunal-closing-its-doors.

135. U.N. Dep't of Pub. Info., The Justice and Reconciliation Process in Rwanda (Mar. 2014), http://www.un.org/en/preventgenocide/rwanda/pdf/Backgrounder\%20Justice\%202014.pdf.

136. See generally OFFICE OF THE PROSECUTOR, INT'L CRIMINAL COURT, REPORT ON Preliminary EXamination ACTIVITIES 2014 (2014), https://www.icc-cpi.int/iccdocs/otp/OTP-PreExam-2014.pdf [hereinafter 2014 REPORT]. 


\section{Case Studies}

The justice-first perspective can be seen in the peace processes and peace agreements of many states. The International Criminal Tribunal for the former Yugoslavia was established through U.N. Security Council resolution while the conflict in Bosnia was ongoing. ${ }^{137}$ During the ongoing peace process, the Yugoslavia Tribunal was granted the authority to begin indicting individuals perceived as responsible for atrocities. ${ }^{138}$ The President of the self-proclaimed Republka Srpska Radovan Karadžić and his commanding general, Ratko Mladić, were indicted for war crimes, which prevented them from even attending the peace negotiations at Dayton. ${ }^{139}$ The indictments issued by the ICC provided the international community with moral clarity as to who was responsible for the conflict, and helped to provide a rationale for when the U.N. Security Council ordered a no fly zone and eventual air strikes against the Serbian forces to halt the genocide. In Dayton, Serbia was represented by Slobodan Milošević, and during the negotiations, the New York Times quoted a Yugoslavia Tribunal official saying "[w]e cannot deny that (Milosevic) is a suspect."140 Milošević was indicted in 1999, four years after signing the Dayton Accords, ${ }^{141}$ he was arrested in 2001, and died in prison in 2006 while his trial was ongoing. ${ }^{142}$

In post-genocide Rwanda, prosecution of perpetrators of the genocide was embraced as the means for the restoration of law and order in the state. ${ }^{143}$ Justice was a priority in reconciliation and transitioning after the violence. The International Criminal Tribunal for Rwanda, established by the U.N. Security Council, prosecuted high-level perpetrators of the genocide while domestic tribunals addressed lower-level perpetrators. ${ }^{144}$

137. ICTY, supra note 133.

138. Id.

139. RICHARD H. STEINBERG, CONTEMPORARY IsSUES FACING THE INTERNATIONAL CRIMINAL COURT 218 (2016); see Moments in U.S. Diplomatic History: Negotiating the Dayton Peace Accords, Ass'N FOR DipLOMATIC STUD. \& TRAINING, http://adst.org/2014/11/the-dayton-peace-accords/\#.Wm3li JM-eRs (last visited Apr. 22, 2018).

140. Human Rights in Peace Negotiations, supra note 2, at 256.

141. Michael P. Scharf, The Indictment of Slobodan Milosevic, AM. SOC'Y INT'L L., June 5, 1999, https:/www.asil.org/insights/volume/4/issue/3/ind ictment-slobodan-milosevic.

142. Marlise Simons \& Alison Smale, Slobodan Milosevic, 64, Former Yugoslav Leader Accused of War Crimes, Dies, N.Y. TimEs (Mar. 12, 2006), www.nytimes.com/2006/03/12/world/euro $\mathrm{pe} / \mathrm{slobodan}$-milosevic-64-former-yugoslav-leader-accused-of-war.html.

143. Izabela Steflja, Challenges of Transitional Justice in Rwanda 1 (2012), https:/www.africaportal.org/publications/challenges-of-transitional-justice-in-rwanda/.

144. Id. at 1-2. 
Additionally, the gacaca courts, a traditional justice system, provided truth and reconciliation at the community-level. ${ }^{145}$

In some instances, the ICC has also begun prosecution efforts through its own initiative or at the request of states while parties are negotiating or after parties have reached agreement, thus prioritizing justice through its own volition. ${ }^{146}$ In 2004, the Ugandan government referred its conflict with the LRA to the ICC. ${ }^{147}$ In 2005, in Uganda, the ICC issued arrest warrants for high-level members of the LRA, including its leader Joseph Kony, while negotiations between the LRA and the government were ongoing. ${ }^{148}$ All suspects remain at large, except Dominic Ongwen, who surrendered himself in 2015. ${ }^{149}$ A draft comprehensive peace agreement in 2008, which was ultimately not signed by Kony, also prioritized justice, providing for a special chamber in the Ugandan courts to prosecute LRA leaders. ${ }^{150}$ Based on the draft peace agreement language, the International Crimes Division is a special Division of High Court of Uganda and is designed to operate in parallel to the ICC. ${ }^{151}$

In Sudan the ICC also issued arrest warrants to begin prosecution efforts for atrocities that took place in Darfur while the peace process was underway. ${ }^{152}$ The arrest warrants included a warrant for the President of Sudan, Omar al-Bashir. ${ }^{153}$ The Sudanese government strongly protested the ICC's actions and has refused to cooperate with investigations or the arrest warrants. ${ }^{154}$ Regional institutions, including the African Union, voiced support of the Sudanese government's protests. ${ }^{155}$

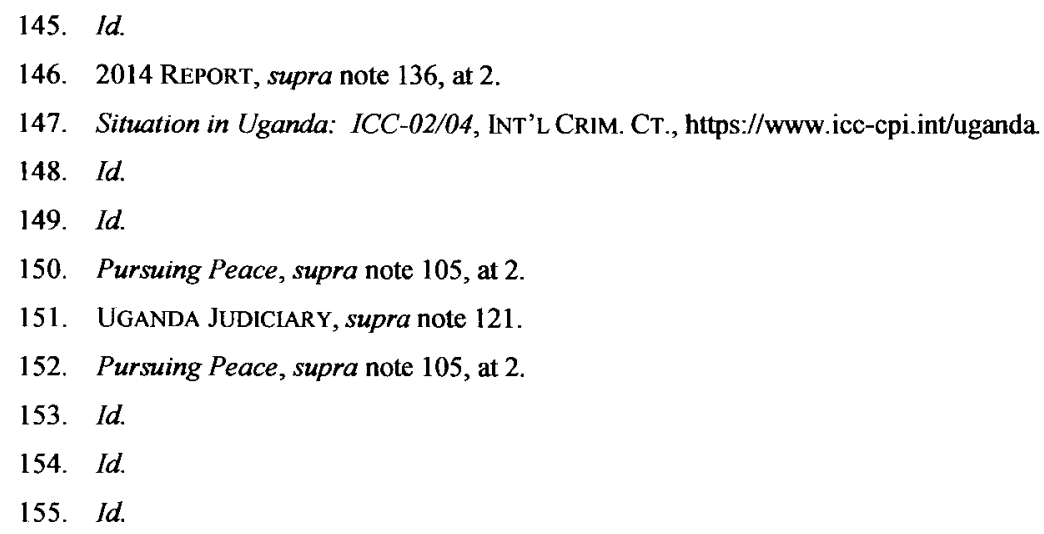




\title{
IV. PEACE WITH JUSTICE
}

\author{
"We have learned that the rule of law delayed is lasting peace denied, and that \\ justice is a handmaiden of true peace." 156 \\ Kofi Annan, former Secretary General of the United Nations
}

The purpose of this section is to identify the core components of a third approach to the peace versus justice puzzle: peace with justice. The peace-first approach highlights the obstacles to peace (and the resolution of conflict) posed by the pursuit of justice. The justice-first approach on the other hand, underscores the impossibility of sustainable peace absent genuine accountability. The "peace with justice" approach, meanwhile, advances the notion that peace and justice are not quite so mutually exclusive as the former two approaches would indicate-rather, in certain circumstances parties to a negotiation can artfully weave the two together. ${ }^{157}$ There are a variety of techniques by which to accomplish this. ${ }^{158}$ This section will provide a brief overview of the "peace with justice" approach, followed by a discussion of the primary mechanisms or techniques for pursuing both peace and justice. The complicated interplay of these various mechanisms is illustrated by the diverse attempts to build a "peace with justice" framework in Colombia, Sierra Leone, the Côte d'Ivoire, and Cambodia. ${ }^{159}$

There is an emerging third approach to the peace versus justice puzzle. This approach claims that parties to a conflict can mutually pursue peace

156. Statement, Secretary-General's Remarks to the Ministerial Meeting of the Security Council on Justice and the Rule of Law: The United Nations Role, U.N. Statement S/PV4833 (Sept. 24, 2003).

157. Bartłomiej Krzan, International Criminal Court Facing the Peace vs. Justice Dilemma, 2 INT'L COMP. JURIS. 81, 81 (2016); see generally Alex Whiting, An Investigation Mechanism for Syria: The General Assembly Steps into the Breach, 15 J. INT'L CRIM. JUST. 231 (2017); Gabriella Blum, The Crime and Punishment of States, 38 YALE J. INT'L L. 57 (2013); WILLIAM SCHABAS, KEIN FRIEDEN oHnE Gerechtigkeit?: DIE Rolle der internationalen StrafJustiz [No PEace without Justice? THE Role of InTERNATIONAL CRIMINAL LAW] (Edith Nerke \& Jürgen Bauer trans,, 2013) [hereinafter No PEACE WITHOUT JusTICE]; Linda M. Keller, The False Dichotomy of Peace Versus Justice and the International Criminal Court, 3 HAGUE JUST. J. 12 (2008); Beth Van Schaack, International \& US Support for Transitional Justice Initiatives, JUST SECURITY (July 1, 2016), https://www.justsecurity.org/31737/international-support-transitional-justice-initiatives/.

158. See, e.g., Renée Jeffery, Sequencing Transitional Justice Mechanisms: Lessons from the Solomon Islands, MIDDLE E. INST. (Mar. 4, 2014), http:/www.mei.edu/content/sequencingtransitionaljustice-mechanisms-lessons-solomon-islands; Paul Gready \& Simon Robins, From Transitional to Transformative Justice: A New Agenda for Practice, 8 INT'L J. TRANS. JUST. 339, 344 (2014).

159. See generally Whiting, supra note 157; Blum, supra note 157; Keller, supra note 157; Van Schaak, supra note 157. 
and justice. ${ }^{160}$ This approach rejects the perceived tensions between peace and justice as a "false dichotomy." 161 Under this approach, peace and justice are mutually reinforcing, as opposed to mutually exclusive. ${ }^{162}$ The question, then, becomes not which goal to pursue, but rather when and how. ${ }^{163}$ Although this third approach introduces an intriguing concept, there are ultimately important limitations to this approach as well. ${ }^{164}$

The primary tenets of the "peace with justice" approach can be summarized as:

1) peace and justice are inextricably connected to both reinforce and complement one another;

2) the promotion of both, regardless of how complex and difficult, should be pursued;

3) there is a grave need for peace, but it should be found in conjunction with recognition of the demand for justice; and

4) when mishandled, peace and justice may clash, but peace should never justify impunity. ${ }^{165}$

Supporters of this approach argue that law is a cornerstone to any peace-building mission, and thus, pursuing peace with justice seems a logical step in transitioning a state from conflict to sustainable peace. ${ }^{166}$ By integrating peace with justice during a post-conflict transitional period, peace-builders can provide oversight both to the laying down of arms and efforts at capacity-building to administer justice. ${ }^{167}$ Additionally, when peace is combined with justice, the perception of justice may shift from the retributive to the restorative, such that states and citizens more effectively seek reconciliation. Under this view, a framework for long-term peace that contemplates more than an immediate end to a conflict relies on justice to be both sustainable and enduring. ${ }^{168}$ In support of this argument, states can

160. See Krzan, supra note 157 , at 81.

161. Linda M. Keller, Achieving Peace with Justice: The International Criminal Court and Ugandan Alternative Justice Mechanisms, 23 CONN. J. INT'L L. 209, 211 (2008) [hereinafter Achieving Peace with Justice].

162. L.anger et al., supra note 19 , at 183.

163. Id.

164. See generally David BosCo, Rough Justice: The INTERNATIONAL CRIMINAL COURT IN A WORLD OF POWER POLITICS (2014).

165. See Krzan, supra note 157 , at 87.

166. See Off. High Comm'R Hum.RTs., Rule-OF-Law ToOls for Post-Conflict States: MAPPING THE JUSTICE SECTOR, HR/PUB/06/2, 1 (2006).

167. Id.

168. See id. 
take a variety of steps to intertwine peace and justice. These actions include a "sequencing" approach and a "holistic" approach. 169 Additionally, states often incorporate a range of justice-oriented mechanisms that sometimes expand beyond the notion of direct accountability. Further mechanisms for interlacing peace with justice include:
1) non-state justice mechanisms;
2) reparations; and
3) truth-seeking. ${ }^{170}$

\section{A. Methods to Meet the Needs of the State Post-Conflict}

States could use any of these methods, with consideration to which method most meets the needs of the post-conflict state in question.

\section{Sequencing}

As the term suggests, the approach of "sequencing" involves the strategic phasing of various transitional justice mechanisms. ${ }^{171}$ Rather than asking if peace or justice should be pursued, the question then becomes when and how states should pursue both objectives. ${ }^{172}$ With sequencing, there is no need to compromise justice for peace as justice will be pursued after parties reach a peace agreement. ${ }^{173}$ This perspective accepts that justice may be a necessarily long-term goal, but also recognizes the importance of justice and underscores that accountability will eventually manifest. ${ }^{174}$ However, opponents of this process argue that under this approach justice will not occur quickly enough to satisfy citizens and victims, because it takes time to gain the capacity, legitimacy, and independence to review claims or overturn amnesties. ${ }^{175}$

169. Jeffery, supra note 158; Gready \& Robins, supra note 158, at 344.

170. Luc Huyse \& Mark Salter, TRaditional Justice and Reconcillation After VIOLENT CONFLICT: LEARNING FROM AFRICAN EXPERIENCES 3 (2008); see generally Reparations, INT'L CTR. TRANSITIONAL JUST., https://www.ictj.org/our-work/transitional-justice-issues/reparations (last visited Apr. 22, 2018).

171. Jeffery, supra note 158.

172. Krzan, supra note 157 , at 82 .

173. See Prorok, supra note 26 , at 213

174. Jeffery, supra note 158.

175. Daniel Serwer, Justice and Peace: A False Dichotomy, SYRIA JUST. \& ACCT. CTR. (July 25, 2016), https://syriaaccountability_org/updates/2016/07/25/justice-and-peace-a-false-dichotomy/. 


\section{Holistic}

Additionally, states can accomplish peace and justice through holistic measures. ${ }^{176}$ These measures involve non-prosecutorial accountability measures that contribute actively to peace while simultaneously supporting justice. ${ }^{177}$ Potential mechanisms under this holistic understanding include truth and reconciliation commissions, local or traditional justice, public acknowledgment mechanisms, and/or institutional reform. ${ }^{178}$ Alternative methods of justice may be more successful than prosecutorial means of justice. ${ }^{179}$ This framework broadens the approach to transitional justice beyond merely institutional responses, so as to incorporate broader political and social involvement. ${ }^{180}$ Further, these non-prosecutorial mechanisms have similar justice goals to traditional prosecutions:

1) discovering, clarifying, and acknowledging past abuses;

2) responding to victims' needs;

3) contributing to justice and accountability;

4) outlining institutional responsibility and recommending reforms; and

5) promoting reconciliation and reducing conflict. ${ }^{181}$

\section{Non-State Justice Mechanisms}

Non-state justice mechanisms, sometimes referred to as traditional justice, incorporate indigenous and customary practices into the transitional justice process. ${ }^{182}$ For instance, gacaca courts, local community courts inspired by the Rwandan traditional courts, emerged as a traditional mechanism to assist Rwanda's national courts with trials of the 130,000 people imprisoned following the Rwandan genocide. ${ }^{183}$ The U.N. Secretary-General emphasized the vital role of "indigenous and informal traditions for administering justice or settling disputes," while conforming

176. Gready \& Robins, supra note 158 , at 344.

177. Id.

178. Id.

179. See Achieving Peace with Justice, supra note 161, at 209, 212-13, 227.

180. Gready \& Robins, supra note 158, at 344.

181. Diba Majzub, Peace or Justice? Amnesties and the International Criminal Court, 3 MELB. J. INT'L L. 247, 261 (2002).

182. HUYSE \& SALTER, supra note 170.

183. Id. at 37 . 
with international law to ensure the inclusion of all groups in the justice process. ${ }^{184}$

\section{Reparations}

Granting reparations, meanwhile, is an internationally recognized method of restoring victims of serious crimes to their financial, physical, or psychological position before suffering the harm in question. ${ }^{185}$ Victims' reparations can take multiple forms, including restitution, compensation, rehabilitation, satisfaction, and guarantees of non-repetition. ${ }^{186}$ Whatever the form of reparations, the purpose of the mechanism is to provide a meaningful response to the harm suffered, that can be tailored to the specific context, needs, and priorities of the victim in question-and in doing so, this mechanism can theoretically meet at least some of the underlying purposes of accountability.

\section{Truth-Seeking}

Truth-seeking is the process of investigating past human rights violations to determine what happened, why it happened, and to what effect in order to prevent future abuses. ${ }^{187}$ Mechanisms for truth-seeking include truth commissions, commissions of inquiry, and fact-finding missions. ${ }^{188}$ Truth commissions are either non-judicial or quasi-judicial bodies that investigate past abuses to establish the truth of the violations and to publish a final report that can make policy recommendations, disseminate victims' voices, and serve as a historical record. ${ }^{189}$ There have been over forty truth

184. U.N. Secretary-General, The Rule of Law and Transitional Justice in Conflict and PostConflict Societies, ๆ 36, U.N. Doc. S/2004/616 (Aug. 23, 2004). Nonetheless, non-state trials may not be adequate in ethnically or religiously diverse states because each group may develop its own prosecutorial system, which may result in unequal treatment. HUYSE \& SALTER, supra note 170, at $182-83$.

185. Reparations, supra note 170.

186. See Pablo De Greiff, Justice and Reparations, in THE HANDBOOK OF REPARATIONS 451, 452-53 (Pablo De Greiff ed., 2006); INTER-AM. INST. HuM. RTS., CONTRIBUTION OF TruTH, JUSTICE, AND ReParation POlicies to LATIN AMERICAN DEMOCRACIES 88 (2011).

187. Int'l Center for Transitional Justice \& KontraS, Derailed: Transitional Justice In INDONESIA SINCE THE FALl of SOEHARTo 9, 17 (2011); see also U.N. Secretary-General, United Nations Approach to Transitional Justice: Guidance Note of the Secretary-General, 8 (Mar. 2010), https://www.un.org/ruleoflaw/files/TJ_Guidance_Note_March_2010FINAL.pdf [hereinafter U.N. Approach to Transitional Justice].

188. U.N. Approach to Transitional Justice, supra note 187 , at 8.

189. Truth Commissions, INT'L CTR. TRANSITIONAL JUST. (2008), http://ictj.org/sites/default/ files/lCTJ-Global-Truth-Commissions-2008-English.pdf; see also Integrated Disarmament, Demobilization and Reintegration Standards: 6.20 DDR and Transitional Justice, U.N. DISARMAMENT, 
commissions over the last three decades, ${ }^{190}$ highlighting the popularity (and potentially the utility) of these mechanisms. Depending on the objective pursued, truth commissions allow for both the victims to tell their story and the perpetrators to admit the crimes they committed in order to promote forgiveness and reconciliation. ${ }^{191}$ Similar to truth commissions, commissions of inquiry and fact-finding missions investigate past human rights abuses to discover the truth but follow narrower mandates ${ }^{192}$ that focus on a particular event, category of crime, or time period. ${ }^{193}$

\section{B. Peace with Justice in Colombia}

The peace process in Colombia reflects one manifestation of the peace with justice approach. In particular, elements of both peace and justice approaches were integrated into the agreement that was ultimately adopted in Colombia in December 2016. ${ }^{194}$ This agreement, between the Colombian government and the FARC, included the establishment of a

Demobllization, \& Reintegration ResourCe CTR. 3 (Dec. 2009), https://www.ictj.org/sites/default/ files/UN-DDR-and-Transitional-Justice-2009-English.pdf.

190. Kieran McEvoy et al., Criminology and Transitional Justice, in THE OXFORD HANDBOOK OF CRIMINology 391, 392 (Alison Liebling et al. eds., 6th ed. 2017); OfF. HigH CoMm'R Hum. RTS., Rule-OF-LAw TOOLS For Post-Conflict States: TRUTH COMmissions, HR/PUB/06/1, 1 (2006), http://www.ohchr.org/Documents/Publications/RuleoflawTruthCommissionsen.pdf; see Essential Best Practices for Truth Commissions, INT'L CTR. FOR TRANSITIONAL JUST. 1 (Dec. 2009), http://www. iccnow.org/documents/CTJ_SDN_briefing_AUPD-TJRC.pdf; Truth and Memory, INT'L CTR. FOR TRANSITIONAL JUST., http://ictj.org/our-work/transitional-justice-issues/truth-and-memory (last visited Apr. 22, 2018).

191. U.S. DEP'T STATE, Truth Commissions (May 16, 2016), https://www.state.gov/documents/ organization/257772.pdf.

192. See U.N. Approach to Transitional Justice, supra note 187 , at 8.

193. JANE ALEXANDER, DEP'T FOR INT'L DEV., A SCOPING STUDY OF TRANSITIONAL Justice AND POVERTY REDUCTION 32 (2003), http://www.gsdrc.org/docs/open/ssaj56.pdf. While such mechanisms are particularly useful to establish the truth, a restrictive mandate may also result in overlooking certain abuses. Id. In Sri Lanka, for instance, the United Nations expresses serious concerns over the mandate of the three Commissions of Inquiry into the Involuntary Removal or Disappearances of Persons, which was limited not only in terms of geographic and temporal scope, but also as to the types of human rights violations under review. Id; see also U.N. Office of the High Commissioner, OHCHR Technical Note: The Nepal Act on the Commission on Investigation of Disappeared Persons, Truth and Reconciliation, 2071 (May 21, 2014), http://www.ohchr.org/documents/ countries/np/ohchrtechnical_note_nepal_cidp_trc_act2014.pdf; Commissions of Inquiry: Sri Lanka, U.S. INST. PEACE (Jan. 1, 1995), https://www.usip.org/publications/1995/01/commissions-inquiry-srilanka.

194. Nicholas Casey, Colombia Signs Peace Agreement with FARC After 5 Decades of War, N.Y. TIMES (Sept. 26, 2016), https:/www.nytimes.com/2016/09/27/world/americas/colombia-farcpeace -agreement.html [hereinafter Casey, Colombia Signs]. 
justice mechanism that offers amnesty. ${ }^{195}$ The provisions of the agreement emphasize the importance of "consolidating peace and realizing the rights of victims," the "promot[ion of] a stable and lasting peace," and the Colombian state's responsibility to "investigate, clarify, prosecute and sanction serious violations of IHRL [international human rights law] and IHL [international humanitarian law]." 196 These provisions reflect the blend of peace and justice that the agreement strives to accomplish.

In particular, the peace deal included provisions to establish a Comprehensive System for Truth, Justice, Reparations and Guarantees of Non-Repetition (Comprehensive System) to carry out a comprehensive transitional justice plan, based on a 2015 "Special Peace Jurisdiction" agreement between the Colombian Government and the FARC. ${ }^{197}$ The Special Jurisdiction for Peace was designed to include both a Peace Tribunal and Judicial Panels to address cases of "serious violations of human rights and humanitarian law" committed by FARC members. ${ }^{198}$

Although the justice mechanism has prosecutorial functions, the agreement provides categorically that any perpetrators, who confess to atrocities, will be exempt from prison, jail, or any "equivalent" form of detention. ${ }^{199}$ Instead, those who confess will be given "sanctions' that have a 'restorative and reparative function' ... [.]"200 These sanctions entail "projects" that will be designed to aid victims of the conflict. ${ }^{201}$ FARC members, who were not primarily responsible for the commission of the most serious crimes and who wholly confessed their acts, will receive either amnesty or alternative penalties such as community service and acts of reparation. ${ }^{202}$

195. Id.

196. Acuerdo Final Para la Terminación del Conflicto y la Construcción de una Paz Estable y Duradera [Final Agreement to End the Armed Conflict and Build a Stable and Lasting Peace] ch. 5, (Nov. 24, 2016), http://www.altocomisionadoparalapaz.gov.co/procesosyconversaciones/Documentos \%20compartidos/24-11-2016NuevoAcuerdoFinal.pdf [hereinafter Final Agreement].

197. Carrillo-Santarelli, supra note 122; Alejandro Valencia Villa, Challenges Facing the Truth Commission of Colombia, Peace Progress: SeEkING TruTH (May 2017), http:/www.icipperlapau.cat/numero31/articles_centrals/article_central_4/.

198. Final Agreement, supra note 196, at 182; Human Rights Watch Analysis of ColombiaFARC Agreement, HuM. RTS. WATCH (Dec. 21, 2015, 6:21 PM), https://www.hrw.org/news/2015/ 12/21/human-rights-watch-analysis-colombia-farc-agreement.

199. Final Agreement, supra note 196.

200. Human Rights Watch Analysis of Colombia-FARC Agreement, supra note 198.

201. Id.; Final Agreement, supra note 196, at 182.

202. Final Agreement, supra note 196, at ch. 5.1.2.III; José Miguel Vivanco, Colombia Peace Deal's Promise, and Flaws, HuM. RTs. WATch (Sept. 27, 2016, 10:39 AM), https://www.hrw.org/news/ 2016/09/27/colombia-peace-deals-promise-and-flaws. 
If, however, FARC members refuse to confess, provide false testimony, or fail to make an honest confession in a timely manner, they will be prosecuted in the Colombian criminal justice system-although they may achieve a reduced sentence by making a partial confession. ${ }^{203}$ Those who take responsibility but do not do so in a timely manner may face a five to eight year prison sentence. ${ }^{204}$ Those who do not confess at all and are found guilty will serve a fifteen-to-twenty year prison sentence. ${ }^{205}$ Conversely, an individual who committed gross human rights violationssuch as gender-based war crimes and crimes against humanity-will not be eligible to receive amnesty and will face criminal prosecution. ${ }^{206}$ Even then, those who immediately confess their crimes may receive a less severe punishment, such as a non-prison detention restriction on their liberty. ${ }^{207}$

The contours of the 2016 peace agreement draw on earlier Colombian practice. ${ }^{208}$ In many ways, the 2016 agreement followed the accountability framework that had been previously utilized to demobilize various antiFARC paramilitary groups, in particular the Justice and Peace Law in 2005. ${ }^{209}$ To support demobilization, the Law allowed individuals that participated voluntarily to take part in a truth-telling process via a special prosecution tribunal. ${ }^{210}$ If fighters participated in this truth-telling process, they were eligible for reduced sentences or even amnesties. ${ }^{211}$ In practice, these mechanisms provided around ninety percent of the paramilitary members with what is essentially de facto amnesty. ${ }^{212}$

The peace agreement introduced in 2016 attempted to draw from this past Colombian experience, so as to strike a fine balance between peace and

203. Final Agreement, supra note 196, at ch. 5.1.2.II.60; Carrillo-Santarelli, supra note 122.

204. Final Agreement, supra note 196, at ch. 5.1.2.2.II; Colleen Murphy, Colombia's Special Jurisdiction for Peace, U. ILL. (Oct. 9, 2017), https://will.illinois.edu/legalissuesinthenews/program/ colombias-special-jurisdiction-for-peace.

205. Final Agreement, supra note 196, at ch. 5.1.2.2.III; Murphy, supra note 204.

206. Final Agreement, supra note 196, at ch. 5.1.2.II.40.

207. Id. at ch. 5.1.2.1II.60; Carrillo-Santarelli, supra note 122.

208. Paul Williams \& Tiffany Sommadossi, The Colombian Referendum: A Lesson on Peace Without Justice, HUFFPOST (Oct. 7, 2016, 2:33 PM), https://www.huffingtonpost.com/entry/thecolombian-referendum-a-lesson-on-peace-without_us_57f7d9dfe4b090dec0e71064

209. Id.; see generally L. 975, julio 25, 2005, Diario OfICIAL [D.O.] (Colom.).

210. Williams \& Sommadossi, supra note 208; see generally L. 975 , julio 25, 2005, DIARIO OFICIAL [D.O.] (Colom.).

211. See generally L. 975, julio 25, 2005, DiARIO OfICIAL [D.O.] (Colom.); Colombia: The Justice and Peace Law, CTR. FOR JUST. \& ACCOUNTABILITY, http://cja.org/where-we-work/colombia/ related-resources/colombia-the-justice-and-peace-law/ (last visited Apr. 22, 2018).

212. Colombia: The Justice and Peace Law, supra note 211. 
justice. ${ }^{213}$ Indeed, Colombian President Santos, one of the architects of the peace agreement, highlighted in reference to the agreement that "perfect justice would not allow peace."214 Instead, President Santos argued that the deal "achieves as much justice as possible while transitioning from conflict to peace." 215 Ultimately, the system proposed was closer to an amnesty based truth and reconciliation commission, than a true direct accountability system. ${ }^{216}$

In October 2016, the (already signed) peace agreement was put to a popular referendum. ${ }^{217}$ To the surprise of many, $50.24 \%$ of the population voted to reject the peace agreement, and the referendum failed. ${ }^{218}$ The primary concerns of those who voted to reject the peace agreement centered, in large part, on the balance of justice interlaced into the agreement. ${ }^{219}$ For instance, one major concern was the legal immunity for rank-and-file soldiers of the FARC, ${ }^{220}$ who were allegedly responsible for crimes including murder, kidnapping, and rape against civilians. ${ }^{221}$ Another concern was the lack of defining details for the tribunal in which FARC leaders were to be tried, combined with the opportunity for FARC leaders to receive reduced sentences or potentially even amnesty in return for early confessions. 222

An additional barrier to adopting the agreement was the agreement's commitment to provide FARC fighters with a monthly stipend for two years, and the provision of $\$ 2500$ payments to individual ex-combatants to start a business. ${ }^{223}$ The ability of the FARC to restructure into a political party under the peace deal was also a divisive issue. ${ }^{224}$ Moreover, the agreement permits FARC members not serving prison sentences to run for

213. Final Agreement, supra note 196, at ch. 5.1.3.1.

214. Vivanco, supra note 202.

215. Id.

216. Rahul Srivastava, The Colombian Peace Referendum, ST ANDREWS FOREIGN AFF. REV. (Oct. 7, 2016), http://foreignaffairsreview.co.uk/2016/10/the-colombian-peace-referendum/.

217. $I d$.

218. Id.

219. Id.

220. Id.

221. Srivastava, supra note 216.

222. Id.

223. Id.

224. Colombia Referendum: Voters Reject FARC Peace Deal, BBC NEws (Oct. 3, 2016), http:/www.bbc.com/news/world-latin-america-37537252. 
office, and grants the FARC ten congressional seats for two terms. ${ }^{225}$ In other words, there was a poignant concern-held by various international human rights organizations in addition to the Colombian population - that those most responsible for the commission of atrocity crimes would not be held sufficiently accountable for their participation in the conflict. ${ }^{226}$

Following the rejection of the peace agreement in the October 2016 referendum, the draft agreement was submitted to the Colombian Congress for revisions. ${ }^{227}$ Colombia's Congress approved a revised version of the agreement, ${ }^{228}$ and the public did not vote on the revised document. ${ }^{229}$ The Agreement included over fifty changes to the version introduced in the referendum. ${ }^{230}$ The new provisions of the agreement clarified the process for prosecuting FARC members responsible before the special court. ${ }^{231}$ However, the new agreement did not provide for prison sentences for those who confessed to war crimes. ${ }^{232}$ The reasoning for this was that doing so would cause the FARC to walk away from the peace agreement. ${ }^{233}$ The new agreement also included a provision requiring the FARC to relinquish assets, some of which were acquired through drug trafficking, to contribute to a fund for compensating victims. ${ }^{234}$ The agreement also did not introduce limitations to the FARC's ability to engage as a political party.

225. Colombia's Congress Approves Peace Tribunals for ex FARC Rebels, REUTERS (Nov. 28, 2017, 6:48 AM), https://www.reuters.com/article/us-colombia-peace/colombias-congress-approvespea ce-tribunals-for-ex-farc-rebels-idUSKBNIDS1C6.

226. Vivanco, supra note 202.

227. Stephen Gill, Colombia's Congress to Vote on Peace Deal Next Week, ColoM. REP. (Nov. 24, 2016), https://colombiareports.com/colombias-congress-vote-peace-deal-next-week/.

228. Nicholas Casey, Colombia's Congress Approves Peace Accord with FARC, N.Y. TIMES (Nov. 30, 2016), https://www.nytimes.com/2016/11/30/world/americas/colombia-farc-accord-juanmanu el-santos.html?_ $\mathrm{r}=0$ [hereinafter Casey, Colombia's Congress].

229. Id.

230. Associated Press, Colombia's Government Formally Ratifies Revised Farc Peace Deal, GUARDIAN (Dec. 1, 2016, 3:27), https://www.theguardian.com/world/2016/dec/01/colombiasgovern ment-formally-ratifies-revised-farc-peace-deal [hereinafter Associated Press, Colombia]. 228.

231. Final Agreement, supra note 196, at ch. 5.1.2; Casey, Colombia's Congress, supra note

232. Casey, Colombia's Congress, supra note 228.

233. Id

234. Associated Press, Colombia, supra note 230.

235. Id. 
Ultimately, in December 2016 the revised peace agreement went into effect, ${ }^{236}$ and preparations for its implementation began. In assessing the justice framework introduced as a result, it is also worth noting that Colombia has also ratified the ICC, and therefore, the domestic mechanisms under the agreement will operate while ICC investigations and preliminary examinations in Colombia continue to function in parallel. ${ }^{237}$ The ICC opened a preliminary examination of the situation in Colombia in June 2004 , on alleged crimes against humanity and war crimes. ${ }^{238}$ This preliminary examination is ongoing as of 2018 , and most recently has included field visits by the ICC to clarify various aspects of the Special Jurisdiction for Peace. ${ }^{239}$

\section{Peace with Justice in Sierra Leone}

Sierra Leone presents another instance of peace interwoven with justice, although distinct from the Colombian context. In particular, the Sierra Leone experience illustrates the practice of providing broad amnesty. via a peace agreement, combined with targeted, high-level prosecutions. The 1999 Lomé Peace Agreement contained an amnesty provision that prevented prosecutions for acts criminalized under Sierra Leonean law. ${ }^{240}$ In 2000, a hybrid Truth and Reconciliation Commission was established with the broad purpose of truth-telling and establishing a historical record of atrocities. ${ }^{241}$ In 2002, however, the Special Court for Sierra Leone (a hybrid tribunal) was established by U.N. Security Council Resolution 1315, with the purpose of prosecuting crimes under both international law and Sierra Leone's domestic law. ${ }^{242}$

236. Sibylla Brodzinsky, 'Welcome to Peace': Colombia's Farc Rebels Seal Historic Disarmament, GUARDIAN (June 27, 2017, 15:30), https://www.theguardian.com/world/2017/jun/27/colo mbia-farc-weapons-war-government.

237. Colombia, COALITION FOR INT'L CRIM. CT., http://www.coalitionfortheicc.org/country/ colombia (last visited Apr. 22, 2018).

238. Preliminary Examination: Colombia, INT'L CRIM. CT., https://www.icc-cpi.int/colombia (last visited Apr. 22, 2018).

239. Statement of the Prosecutor of the International Criminal Court, Fatou Bensouda, on the Conclusion of Her Visit to Colombia, INT'L CRIM. CT. (Sept. 13, 2017), https://www.icccpi.int// Pages/item.aspx?name=170913-otp-stat-colombia.

240. Peace Agreement Between the Government of Sierra Leone and the Revolutionary United Front of Sierra Leone, transmitted by Letter Dated 12 July 1999 from Kodjo Menzan of the Security Council, art. LX, ๆ 2, S/1999/777 (July 7, 1999).

241. The Truth and Reconciliation Commission Act $2000 \S 6(1)$, http://www.sierraleone.org/Laws/2000-4.pdf.

242. S.C. Res. 1315 , १ๆ 1-2 (Aug. 14, 2000). 
Controversy arose in relation to the interpretation of the amnesty provisions of the Lomé Peace Agreement, in light of the prosecutorial framework of the Special Court. In theory, the amnesty provisions of the peace agreement would have prevented the Special Court from pursuing charges for acts criminalized under Sierra Leonean law. ${ }^{243}$ However, the Special Court itself interpreted the amnesty provision as inapplicable to the prosecution of international crimes. ${ }^{244}$ This interpretation found support in the U.N.'s approach as the guarantor of the Lomé Agreement; in clarifying the peace agreement, the U.N. stated that the amnesty and pardon article was inapplicable to international crimes of genocide, crimes against humanity, war crimes, and other serious violations of international humanitarian law. ${ }^{245}$ On this basis, the Special Court proceeded with prosecutorial action for a select pool of high-level perpetrators, culminating its work with the conviction of former Liberian President Charles Taylor. ${ }^{246}$

\section{Peace with Justice in the Côte d'Ivoire}

Following the atrocities suffered by civilians in the Côte d'Ivoire's 2010-2011 post-election crisis, ${ }^{247}$ newly-elected President Ouattara established a Special Investigation and Examination Cell, composed of judges and prosecutors, to take steps against those most responsible for atrocity crimes. ${ }^{248}$ In 2015, the Special Cell charged more than twenty individuals, including high-level commanders from both sides. ${ }^{249}$ A national truth commission, the Dialogue, Truth, and Reconciliation Commission (CDVR), was also established in 2011 to investigate

243. Statute of the Special Court for Sierra Leone, art. 10 (2000), http://www.rscsl.org/ Documents/scsl-statute.pdf.

244. Prosecutor v. Augustine Gbao, Case No. SCSL-2004-14-AR72(E), Decision on Preliminary Motion of the Invalidity of Agreement between the UN and Government of Sierra Leone on Est. of Special Court, para. II.9 (May 25, 2004), http://hrlibrary.umn.edu/instree/SCSL/SCSL-04-15T/Appeal_Decision.htm.

245. S.C. Res. 1315, 1 1-1, (Aug. 14, 2000); see There Can be No Amnesty for Genocide and War Crimes - Annan, U.N. News (Aug. 12, 2004), http://www.un.org/apps/news/story.asp?NewsID= 11615.

246. Open Soc'y Justice initiative, The Trial of Charles taylor by the Special COURT FOR SIERRA LEONE: THE APPEAL JUDGMENT 2 (2013), https://www.opensocietyfoundations. org/sites/default/files/charles-taylor-appeal-brief-20130924_0.pdf.

247. Côte d'Ivoire: 5 Years on, Awaiting Justice, HUM. RTs. WATCH (Mar. 22, 2016, 12:01 AM), https://www.hrw.org/news/2016/03/22/cote-divoire-5-years-awaiting-justice.

248. Id.

249. Id. 
violations. ${ }^{250}$ By the time the CDVR's mandate concluded in 2014, the entity took statements from more than 72,000 Ivorian nationals. ${ }^{251}$ The final report was provided to President Ouattara, who did not make the report publicly-available but did commit approximately $\$ 16.2$ million to indemnify victims on its basis. ${ }^{252}$ A new commission, the National Commission for Reconciliation and Indemnification of Victims, was established in March 2015 to oversee a reparations program for victims of an even wider range of abuses, committed between 1990 and 2012. ${ }^{253}$ This package provided a blend of peace-prioritizing mechanisms with measures for justice that expanded beyond traditional direct accountability.

Additional aspects of direct accountability also filtered into the Côte d'Ivoire context. For instance, in January 2016 the ICC initiated a joint trial of former president Laurent Gbabgo and Charles Ble Goude for crimes against humanity committed in the course of the post-election crisis. ${ }^{254}$ The ICC also sought Simone Gbagbo, the former first lady who remained in Ivoirian custody where she was tried and convicted for "crimes against the state." 255 When the ICC claimed that she should be prosecuted for atrocity crimes in The Hague, the Côte d'Ivoire charged her with crimes against humanity and retained jurisdiction as a form of "positive complementarity"256 although she was ultimately acquitted of the specific crimes against humanity charges. ${ }^{257}$ Meanwhile, former President Gbagbo's trial started in 2016, and he remains in ICC custody as prosecutions continue. ${ }^{258}$ In 2015 Ouattara was peacefully re-elected. ${ }^{259}$ Although not all issues are settled (for example, protests broke out in 2016

250. Virginie Ladisch \& Joanna Rice, Cote d'Ivoire Youth Find Voice Through Storytelling, ICTJ (Oct. 27, 2016), https:/www.ictj.org/news/cote-divoire-youth-political-voice-stories-war.

251. Jim Wormington, Human Rights Watch, "To CONSOlidate this PEACE OF OURS": A Human Rights AGENDA FOR COTE D'IvorRe (Corinne Dufka ed., 2015), https://www.hrw.org/ report/2015/12/08/consolidate-peace-ours/human-rights-agenda-cote-divoire.

252. Id.

253. Id.

254. Côte d'lvoire: 5 Years on, Awaiting Justice, supra note 247.

255. Id.

256. Mark Kersten, Hold Your Horses, ICC Complementarity, JUST. IN CONFLICT: BLOG (June 21, 2016), https://justiceinconflict.org/2016/06/21/hold-your-horses-icc-complementarity/.

257. Côte d'lvoire: Simone Gbagbo Acquitted After Flawed War Crimes Trial, HUM. RTS. WATCH (Mar. 29, 2017, 12:00 AM), https://www.hrw.org/news/2017/03/29/cote-divoire-simonegbag bo-acquitted-after-flawed-war-crimes-trial.

258. Prosecutor v. Gbagbo \& Blé Goudé, ICC-02/11-01/15, https://www.icccpi.int/cdi/gbagbogoude.

259. Cote d'voire: Partial Justice, AL JAZEERA (Jan. 26, 2017, 15:02), https://www. aljazeera.com/programmes/peopleandpower/2017/01/cote-partial-justice-170126114050818.html (citing the filmmaker's Victoria Baux view). 
in relation to various constitutional reforms) violence has largely settled and economic growth is on the horizon. ${ }^{260}$

\section{E. Peace with Justice in Cambodia}

Lastly, the Cambodian context provides an instance of peace with justice, via sequencing. After a decade-long armed conflict between Cambodia and Vietnam, the Paris Peace Accords were signed in 1991. ${ }^{261}$ The Paris Peace Accords formalized an arrangement that maintained the Cambodian Khmer Rouge in political power despite its responsibility for significant atrocities in Cambodian territory. ${ }^{262}$ In doing so, and in its more general avoidance of addressing the issue of atrocity crimes, the Paris Peace Accords effectively provided the Khmer Rouge with impunity. ${ }^{263}$ In effect, the Cambodian peace process prioritized peace and stability, over accountability.

Justice, however, was eventually introduced into the Cambodian context in a later period, following the securement of peace. More than fifteen years after the signing of the Paris Peace Accords, efforts for direct accountability culminated in the establishment of the Cambodian Tribunal (a hybrid tribunal) in 2006. ${ }^{264}$ The court was established by agreement between the U.N. and the government of Cambodia. ${ }^{265}$ The purpose of the court was to prosecute those most responsible for violations of international law and other grave crimes. ${ }^{266}$ Although an imperfect prosecutorial mechanism, to date the court has convicted three perpetrators. ${ }^{267}$

The experiences of Colombia, Sierra Leone, the Côte d'Ivoire, and Cambodia display the diverse methods by which to pursue a "peace with justice framework." These case studies illustrate, to various degrees, the

260. Id.

261. Final Act of the Paris Conference on Cambodia, U.S. INST. PEACE (Feb. 22, 2000) https:/www.usip.org/sites/default/files/file/resources/collections/peace_agreements/final_act_10231991 .pdf.

262. Id.; Philip Shenon, Cause for Alarm?; The Peace Treaty Brings the Khmer Rouge into Government, and that Frightens Many, N.Y. TIMES (1991), http://www.nytimes.com/1991/10/24/ world/cause-for-alarm-peace-treaty-brings-khmer-rouge-into-government-that-frightens.html.

263. Shenon, supra note 262.

264. UN-Backed Tribunal Sentences Khmer Rouge Leaders to Life in Prison, UN NEwS (Aug. 7, 2014), http://www.un.org/apps/news/story.asp?NewsID=48433\#.Wn9wzpPwZN1.

265. Id.

266. Id.

267. Seth Mydans, 11 Years, $\$ 300$ Million and 3 Convictions. Was the Khmer Rouge Tribunal Worth It?, N.Y. Times (Apr. 10, 2017), https:/www.nytimes.com/2017/04/10/world/asia/cambodiakhmer-rouge-united-nations-tribunal.html. 
potential utility of developing transitional mechanisms for justice, providing general amnesties combined with targeted prosecutions, or sequencing justice mechanisms following the establishment of peace and stability. Although not without its limitations, this approach demonstrates that in certain circumstances parties to a negotiation can choose to interweave peace with justice, rather than pursuing one at the total expense of the other.

\section{THE SYRIAN CRISIS}

The purpose of this section is to explore the interplay between the approaches of peace-first and justice-first in the context of the Syrian conflict. The Syrian conflict is characterized by initial uncertainty as to whether the peace-first approach or the justice-first approach would take predominance in the peace process. After a pivotal failed effort at the U.N. Security Council to instill significant justice measures into the Syrian context, the Syrian process evolved towards a peace-first approach by those seeking to end, or at least manage, the conflict. However, despite the traction that the peace-first approach has gained in the Syrian context, there are persistent efforts by key actors to weave accountability into the peace process. While these efforts have had a relatively minor impact on the process, and it is clear the approach to resolve the Syrian crisis will not be one of justice-first, it remains to be seen whether the final stretch of the peace process is driven by a peace-first approach, or whether a peace with justice approach is able to emerge. The seedling efforts towards accountability that are being instilled into the process now, may ultimately lay the foundation for moving towards a more focused accountability in the future.

In order to explore the interplay between the approaches of peace-first and justice-first in the context of the Syrian conflict, this section will briefly review the origins of the conflict, its "spill-in" and multi-dimensional nature, and the U.N. peace process established to resolve the conflict. The section will then trace the efforts of various key stakeholders to weave justice into the peace process through several mechanisms such as U.N. Security Council referral to the ICC, the establishment of a Commission of Inquiry and an International, Impartial, Independent Mechanism, the creation of a number of documentation efforts, a proposal for a Hybrid Tribunal, and the use of universal jurisdiction. 


\section{A. Origins of the Conflict}

The Syrian conflict began with a small group of children writing antigovernment graffiti in Dara. ${ }^{268}$ They were arrested and tortured, sparking nationwide protests, and leading to a multi-dimensional civil war now in its eighth year. ${ }^{269}$ These nationwide protests against the Assad regime swept across the country beginning March $2011,{ }^{270}$ coinciding with the Arab Spring movement that swept through Yemen, Libya, Tunisia, and Egypt. ${ }^{271}$ The Assad regime responded with force and opposition groups began to organize, and arm themselves, leading to the formation of the Free Syrian Army. The Free Syrian Army began to use force in defending against attacks by the Assad regime, and by mid-2011, what began as peaceful protests had transformed into a full-fledged internal conflict. ${ }^{272}$ Fighting has been near-constant since 2011..$^{273}$ The conflict has also since expanded to include a vast number of differing Syrian opposition fighting brigades, as well as foreign terrorist organizations such as Jabhat al Nusra and ISIS. ${ }^{274}$

Since its inception, the Syrian conflict has been marked by widespread and brutal atrocities. The conflict has been characterized by a death toll exceeding 470,000 along with more than 11 million displaced, ${ }^{275}$ the documented torture to death of more than $14,000,{ }^{276}$ the use of internationally prohibited chemical weapons, inherently indiscriminate barrel bombs, cluster munitions, and the indiscriminate use of incendiary

268. Mark MacKinnon, The Graffiti Kids Who Sparked the Syrian War, GLOBE \& MAIL (Dec. 2, 2016), https://www.theglobeandmail.com/news/world/the-graffiti-kids-who-sparked-the-syrian-war/ article33123646/.

269. Id; Avi Asher-Schapiro, The Young Men Who Started Syria's Revolution Speak About Daraa, Where it All Began, VICE NEwS (Mar. 15, 2016, 9:30 AM), https://news.vice.com/article/theyoung-men-who-started-syrias-revolution-speak-about-daraa-where-it-all-began

270. MacKinnon, supra note 268; Syria: The Story of the Conflict, BBC NEWs (Mar. 11, 2016), http:/www.bbc.com/news/world-middle-east-26116868.

271. MacKinnon, supra note 268; Arab Spring: A Research \& Study Guide: Yemen, CORNELL U. LIBR., http://guides.library.comell.edu/c.php?g=31688\&p=200752 (last visited Apr. 22, 2018).

272. Syria: The Story of the Conflict, supra note 270.

273. See Ben Hubbard \& Neil MacFarquhar, New Cease-Fire Begins in Syria, but Violations Are Reported Within Hours, N.Y. TIMES (Dec. 29, 2016), https://www.nytimes.com/2016/12/29/world /middleeast/syria-cease-fire.html; Mackinnon, supra note 268.

274. Syria War: A Brief Guide to Who's Fighting Whom, BBC News (Apr. 7, 2017), http://www.bbc.com/news/world-middle-east-39528673; see Michael Karadjis, US vs Free Syrian Army vs Jabhat al-Nusra (and ISIS), NEW POL. (Dec. 19, 2017), http://newpol.org/content/us-vs-free-syrianarmy-vs-jabhat-alnusra-and-isis.

275. HRW WORLD REPORT: EVENTS OF 2016, supra note 1.

276. AMNESTY INT'L, HUMAN SLAUGHTERHOUSE: MASS HANGINGS AND EXTERMTNATION AT SAYDNAYA PRISON, SYRIA 5-6 (2017), https://www.amnesty.org/en/documents/mde24/5415/2017/en/. 
weapons in civilian-populated areas. ${ }^{277}$ While many of the actors involved in the conflict are responsible for atrocities, the vast majority have been (and continue to be) committed by the Assad regime.

\section{B. Syria-A Multi-Dimensional Spill-In Conflict}

In the Syrian conflict there are least six main groups of domestic forces, along with their international allies, engaged in at least five distinct conflicts. ${ }^{278}$ While most wars run the risk of spilling-over into neighboring states, in the case of Syria the war has spilled into the country, with nearly a dozen external actors directly supporting parties to the conflict and in a number of instances deploying their own forces inside Syrian territory. ${ }^{279}$ The Syrian parties engaged in the conflict include: ${ }^{280}$

1. Government of the Syrian Arab Republic: The current Syrian government, which has been under the executive rule of Bashar al-Assad since July $2000 .{ }^{281}$

2. Free Syrian Army (FSA): Formed in August of 2011 by defectors from the Syrian regime, the Free Syrian Army is one of the predominant Syrian armed opposition groups, comprised of more than fifty fighting factions. ${ }^{282}$

3. Kurdish Forces: The People's Protection Units (YPG) is a Kurdish force that has been active in the Syrian conflict. ${ }^{283}$ The YPG is considered a terrorist organization by the Turkish government, and has been linked to the long-term insurgency war in Turkey.

4. The Syrian Democratic Forces (SDF): A primarily Kurdish force that also includes local Arab militias, the SDF is comprised in large part by YPG fighters. ${ }^{284}$ The SDF are forces particularly

277. HRW WORLD REPORT: EVENTS OF 2016, supra note 1.

278. See generally Zachary Laub, Who Is Fighting in Syria's Civil War?, PBS NEWS Hour (May 8, 2017, 9:28 AM), https://www.pbs.org/newshour/world/fighting-syrias-civil-war.

279. See generally Syria Profile - Timeline, BBC News (Feb. 7, 2018), http://www.bbc.com/ news/world-middle-east-14703995.

280. Syria: Mapping the Conflict, BBC NEws (July 10, 2015), http:/www.bbc.com/news/ world-middle-east-22798391.

281. Julia Zorthian, Who's Fighting Who in Syria, TIME (Oct. 7, 2015), http://time.com/ 4059856/Syria-Civil-War-Explainer/.

282. Guide to the Syrian Rebels, BBC NEwS (Dec. 13, 2013), http:/www.bbc.com/news/ world-middle-east-24403003.

283. Laub, supra note 278.

284. Id.; Syrian Democratic Forces (SDF), SYRIAN CIVIL WAR MAP, https://syriancivilwarmap .com/syrian-democratic-forces/ (last visited Apr. 22, 2018). 
active in northern Syria and benefit from U.S. support in antiISIS operations. ${ }^{285}$

5. Al Qaeda: Al Qaeda in Syria is comprised largely of nonSyrians, with only limited Syrian membership, and over the course of the conflict has transformed into a range of Al Qaeda "linked" organizations, most famously known as "Jabhat alNusra."286 Most recently, this entity has been renamed "Hayat Tahrir al-Sham," or HTS. ${ }^{287}$

6. ISIS: Infamously active in Syria, ISIS in this context is comprised of both Syrian and non-Syrian fighters. ${ }^{288}$

Third party states and paramilitary organizations engaged in the conflict include: 289

1. Russia: Russia established an air base inside of Syria at the invitation of the Assad regime in 2015 and deployed bomber and fighter aircraft as well as special forces. ${ }^{290}$ Russia regularly attacks the Free Syrian Army, the Syrian Democratic Forces, and occasionally ISIS. ${ }^{291}$

2. Iran: Iran deployed military forces and a significant number of the Iranian Revolutionary Guard Corps (IRGC) al-Quds Force. ${ }^{292}$ Iranian forces on the ground in Syria may outnumber the military forces of the Syrian regime. ${ }^{293}$ Iranian forces fight on behalf of the Assad regime and engage primarily in operations

285. Laub, supra note 278.

286. Elizabeth O’Bagy, Middle East Security Report 6: JiHAd IN Syria 10 (2012), http://www.understandingwar.org/sites/default/files/Jihad-In-Syria-17SEPT.pdf.

287. Tahrir al Sham: Al-Qaeda's Latest Incarnation in Syria, BBC NEwS (Feb. 28, 2017), http://www.bbc.com/news/world-middle-east-38934206.

288. Syria Profile - Timeline, supra note 279.

289. Alexandra Zavis, Who's Who in Syria: A Look at 8 Key Players in the War, L.A. TIMES (Oct. 3, 2015, 3:00 AM), http://www.latimes.com/world/middleeast/la-fg-syria-players-syria-war-20151 002-htmlstory.html.

290. Bill Chappell, Russia Begins Airstrikes in Syria After Assad's Request, NPR (Sept. 30, 2015, 8:37 AM), https://www.npr.org/sections/thetwo-way/2015/09/30/444679327/russia-beginscondu cting-airstrikes-in-syria-at-assads-request.

291. Id.; Ryan Browne et al., Russian Forces Fire on US-backed Rebel Group in Syria, Coalition Says, CNN: POLITICS, https://www.cnn.com/2017/09/16/politics/russia-fires-on-us-backedforces/index.html (last updated Sept. 17, 2017, 9:50 PM).

292. David Blair, Almost 700 Iranian Troops and Militia Fighters 'Killed in Syria' to Preserve Bashar al-Assad, TELEGRAPH News (May 10, 2016, 5:51 PM), http//www.telegraph.co.uk/news/ 2016/05/10/almost-700-iranian-troops-killed-in-syria-to-preserve-bashar-al/.

293. Majid Rafizadeh, Iran's Forces Outrumber Assad's in Syria, GATESTONE INST. (Nov. 24, 2016, 3:45 AM), https://www.gatestoneinstitute.org/9406/iran-soldiers-syria. 
against the Syrian Opposition, including the Free Syrian Army, and the Syrian Democratic Forces. ${ }^{294}$

3. Hezbollah: Hezbollah is quite active in the Syrian conflict, and as of 2016 an estimated 7000 Hezbollah fighters were based in Syria. ${ }^{295}$ Hezbollah largely fights in support of the Assad regime, and as such engages primarily in operations against the Syrian Opposition, including the Free Syrian Army. ${ }^{296}$

4. Turkey: Turkey deployed several thousand forces into Syria, ${ }^{297}$ both to protect civilians from attack by the Syrian regime and to prevent Kurdish forces from holding contiguous territory along the Turkish border. Turkey also deploys monitors for the de-escalation zones. ${ }^{298}$ In 2017, Turkey largely succeeded in securing a swathe of territory in northern Syria known as the "Euphrates Shield" area. ${ }^{299}$ Early in the conflict Turkey downed a Russian MiG fighter, which had crossed into its airspace, ${ }^{300}$ but more recently acts in close cooperation with Russia.

5. The United States: The United States provides assistance, including weapons, to both the Free Syrian Army and the Syrian Democratic Forces. ${ }^{301}$ The United States has also conducted air strikes against Al-Qaeda and ISIS as part of a US-led coalition focused on the elimination of ISIS. ${ }^{302}$ Further, the United States has deployed approximately 2000 special forces and an artillery

294. Zavis, supra note 289.

295. U.S. DeP'T OF STATE, Bureau OF COUNTERTERrorism, COUNTRY REPORTS ON TERRORISM $2016 \mathrm{ch} .6$ (2017).

296. Id.

297. Turkey Ends 'Euphrates Shield' Operation in Syria, AL JAZEERA (Mar. 29, 2017), https://www.aljazeera.com/news/2017/03/turkey-ends-euphrates-shield-operation-syria-1703292114289 70.html; Associated Press, Syria is Currently Host to Thousands of Foreign Troops: Who are They and Will they Leave?, HAARETZ (Nov. 28, 2017, 12:56 PM), https://www.haaretz.com/middle-eastnews/thousands-of-foreign-troops-in-syria-but-will-they-leave-1.5627108.

298. Iran, Turkey, Russia to Deploy 500 Observers in Idlib, Syria, ISLAMIC REPUBlic News AGENCY (Sept. 16, 2017, 8:53), http://www.ima.ir/en/News/82665953 (Iran).

299. Turkey Ends 'Euphrates Shield' Operation in Syria, supra note 297.

300. Turkey Shoots Down Russian Warplane on Syrian Border, BBC NEwS (Nov. 24, 2015), http://www.bbc.com/news/world-middle-east-34907983.

301. Molly Hennessy-Fiske, Confused by All Those Groups Fighting in Syria? We Break it Down with Arm Patches, L.A. Times (July 23, 2017, 8:50 AM), http://www.latimes.com/world/ middleeast/la-fg-syria-opposition-patches-2017-htmlstory.html.

302. Elizabeth McLaughlin, Two Years of U.S.-led Airstrikes on ISIS in Syria and Iraq in Numbers, ABC NEws (Aug. 8, 2016, 11:58 AM), http://abcnews.go.com/International/years-us-ledairstrikes-isis-syria-iraq-show/story?id $=41206050$. 
unit inside Syria. ${ }^{303}$ The majority of the United States military efforts in the Syrian context are aimed towards the elimination of ISIS. ${ }^{304}$ Notably, in April of 2017, the United States launched a substantial cruise missile attack against air assets of the Assad regime, in retaliation for the regime's chemical weapons attack on Khan Sheikhoun. ${ }^{305}$ In April of 2018, the United States, this time joined by the United Kingom and France, responded to the regime's chemical weapons attack on Douma with additional targeted strikes against regime military and research assets.

6. United Kingdom, France, and other EU states: These states provide assistance to the Free Syrian Army and have conducted air strikes and deployed special forces against Al-Qaeda and ISIS, particularly as part of the US-led coalition. ${ }^{306}$

7. Saudi Arabia: Saudi Arabia provides funding and weapons to the Free Syrian Army, and allegedly to Al-Qaeda. ${ }^{307}$ As a significant supporter of the Syrian opposition, Saudi Arabia is particularly focused on anti-Assad engagement. ${ }^{308}$

8. Qatar: Qatar provides funding and weapons to the Free Syrian Army, and allegedly to Al-Qaeda. The majority of Qatar's engagement in the Syrian context is particularly focused on anti-Assad engagement, but not necessarily in cooperation with Saudi Arabia. ${ }^{309}$

303. Barbara Star, As ISIS Retreats, US is Set to Reveal Troop Numbers in Syria, CNN: PolTTics (Nov. 24, 2017, 12:29 PM), http:/www.cnn.com/2017/1 1/24/politics/syria-us-troops-numbers/ index.html.

304. Colin H. Kahl et al., a Strategy for Ending the Syrian Civil War 1 (2017), https://s3.amazonaws.com/files.cnas.org/documents/CNASReport-Syria-Final.pdf; McLaughlin, supra note 302 .

305. Michael R. Gordon et al., Dozens of U.S. Missiles Hit Air Base in Syria, N.Y. TumEs (Apr. 6, 2017), https://www.nytimes.com/2017/04/06/world/middleeast/us-said-to-weigh-military-responsesto-syrian-chemical-attack.html.

306. EU May Provide Training to Syrian Rebels, SPIEGEL ONLINE (Mar. 4, 2013, 4:18 PM), http://www.spiegel.de/international/europe/the-eu-is-set-to-support-syrian-rebels-with-military-traininga-886794.html (Ger.); Who is Supplying Weapons to the Warring Sides in Syria?, BBC NEWS (June 14, 2013), http://www.bbc.com/news/world-middle-east-22906965.

307. Who is Supplying Weapons to the Warring Sides in Syria?, supra note 320.

308. Zavis, supra note 289.

309. Amena Bakr, Qatar Runs Covert Desert Training Camp for Syrian Rebels, REUTERS (Nov. 26, 2014, 9:14 AM), https:/www.reuters.com/article/us-mideast-crisis-qatar-syria/qatar-runscove rt-desert-training-camp-for-syrian-rebels-idUSKCN0JA1BX20141126. 
9. Jordan: Jordan provides support to the Free Syrian Army. Jordan is also an active participant in overseeing de-escalation zones in Syrian territory, particularly those in the south. ${ }^{310}$

10. International $\mathrm{Al}$ Qaeda: International Al-Qaeda in Syria has been active in the conflict since 2012. At the outset of its participation, Al-Qaeda openly claimed the goal of removing Assad and creating an Islamic state. Al-Qaeda has continued to present itself as anti-Assad force throughout the duration of the conflict. ${ }^{311}$

11. International ISIS: An offshoot of what was once Al-Qaeda in Iraq, International ISIS in Syria became particularly prevalent beginning in 2013, capturing significant portions of Syrian territory and eventually claiming of Raqqa as its de facto capital. ${ }^{312}$ At the peak of its power, approximately ten million people lived under ISIS control. ${ }^{313}$ ISIS engaged in offenses against Syrian opposition armed groups, the Assad regime, SDF forces, members of the US-led coalition, and others. As of late 2017 the US-led coalition seeking to eliminate ISIS claimed that nearly ninety-eight percent of ISIS-held territory has been liberated. ${ }^{314}$

The U.N. launched peace negotiations soon after the beginning of the conflict. $^{315}$ The peace negotiations have proceeded through a variety of iterations and have produced a certain measure of momentum and accomplishments. ${ }^{316}$

The initial peace negotiations were headed by former U.N. Secretary General Kofi Annan and yielded what has become known as the Geneva Communiqué. ${ }^{317}$ The Communiqué, endorsed by the U.N. Security Council, provided for a new constitution, free and fair elections, the

310. Suleiman Al-Khalidi, Syrian Rebels Resist Jordan Pressure to Hand Over Border Crossing, REUTERS (Oct. 5, 2017, 8:04 AM), https://www.reuters.com/article/us-mideast-crisis-syriajordan/syrian-rebels-resist-jordan-pressure-to-hand-over-border-crossing-idUSKBN1CA116.

311. Valerie Szybala, Al-Qaeda Shows Its True Colors in Syria, ISW (Aug. 1, 2013), http:/www.understandingwar.org/sites/default/files/ISWSyriaUpdate-AlQaeda-TrueColors-Syria.pdf.

312. Islamic State and the Crisis in Iraq and Syria in Maps, BBC NEwS (Mar. 28, 2018), http://www.bbc.com/news/world-middle-east-27838034.

313. Id.

314. Id.

315. Syria: Intra-Syrian Negotiations, UN NEWS, https://news.un.org/en/focus/syria (last visited Apr. 22, 2018).

316. See Press Release, Security Council, Security Council Press Statement on International Meeting on Syra in Astana, U.N. Press Release SC/12701 (Jan. 31, 2017)

317. S.C. Res. 2118, (Sept. 27, 2013). 
establishment of a transitional governing body on the basis of mutual consent, and other components that have collectively come to form the core of the negotiating topics in the Geneva peace negotiations. ${ }^{318}$ The second phase of the peace negotiations was headed by Lakhdar Brahimi ${ }^{319}$ and produced some limited momentum for a Transitional Governing Body designed to create an interim arrangement to transition President Assad from power and set the framework for a new constitution and elections. ${ }^{320}$ The talks stalled when the Assad regime refused to engage in substantive negotiations on a political solution. ${ }^{321}$

Renewed momentum for the peace negotiations culminated in the adoption of U.N. Security Council Resolution 2254 in December 2015, ushering in the third phase of the peace process. ${ }^{322}$ Staffan de Mistura headed the third phase and while producing little in the way of specific accomplishments has continued to provide a venue for the parties in the event a desire for serious negotiations emerges. ${ }^{323}$ The third phase has also expanded to include a parallel process in Astana, Kazakhstan managed by a Russian, Iranian and Turkish Troika focused on de-escalation zones (ceasefires for certain defined areas within the Syrian territory). ${ }^{324}$ Through this process a series of de-escalation zones have been established. ${ }^{325}$ The de-escalation zones have been somewhat successful in limiting the

318. Id.

319. Yasmine Saleh \& Shaimaa Fayed, Syria Agrees to Ceasefire During Eid Holiday: Brahimi, REUTERS (Oct. 24, 2012, 5:39 AM), https://www.reuters.com/article/us-syria-crisisbrahimi/ syria-agrees-to-ceasefire-during-eid-holiday-brahimi-idUSBRE89NOG820121024.

320. Syria Peace Talks Break Up as UN Envoy Fails to End Deadlock, GUARDIAN (Feb. 15, 2014, 10:17), https://www.theguardian.com/world/2014/feb/15/syria-peace-talks-break-up-geneva.

321. Id.

322. S.C. Res. 2254, (Dec. 18, 2015).

323. Tom Miles \& Stephanic Nebehay, U.N. Calls Syria Talks a 'Big Missed Opportunity', Seeks New Ideas, REUTERS (Dec. 14, 2017, 2:04 PM), https:/www.reuters.com/article/us-mideastcrisis-syria-un/u-n-calls-syria-talks-a-big-missed-opportunity-seeks-new-ideas-idUSKBN1E82TD; Tom Miles, U.N. Says Planning for Syria Talks Toward End of Jamuary, ReUTERS (Dec. 22, 2015, 5:37 AM), https://www.reuters.com/article/us-mideast-crisis-syria-un/u-n-says-planning-for-syria-talks-toward-end -of-january-idUSKBNOU513B20151222.

324. Jun Pasaylo, Astana Talks to Fortify Syria Ceasefire Accord, GEOPOL MONITOR, http://www.geopolmonitor.com/astana-talks-fortify-syria-ceasefire-accord/ (last visited Apr. 22, 2018); Syrian War: All You Need to Know About the Astana Talks, AL JAZEERA (Oct. 30, 2017), http://www.aljazeera.com/news/2017/10/syrian-war-astana-talks-171029160554816.html.

325. Final De-Escalation Zones Agreed on in Astana, AL JAZEERA (Sept. 15, 2017), http://www.aljazeera.com/news/2017/09/final-de-escalation-zones-agreed-astana-170915102811730.ht $\mathrm{ml}$. 
violence, although violations by the regime and its allies continue. ${ }^{326}$ At various times during these three phases the U.N. Security Council has adopted resolutions supporting the peace negotiations and ratifying various minor outcomes. ${ }^{327}$

Whatever momentum the Astana and Geneva processes may have introduced for a political settlement, it is important to bear in mind that Assad's position has been strengthened by the facts on the ground. ${ }^{328}$ In particular, with the support of Russia and Iran, the Assad regime has made sweeping gains in retaking territory from ISIS and the Syrian Opposition. ${ }^{329}$ Absent a fundamental change in the military landscape, the Assad regime is likely to maintain a significant military advantage on the ground. Given this entrenchment, the likelihood of direct accountability for Assad or any other high-level perpetrators is diminished, at least for the immediate future.

\section{Seeking to Weave Justice into the Syria Peace Process}

As noted above, the Syrian peace process began with uncertainty towards how to resolve the peace versus justice puzzle - would a peace-first approach take hold, or would efforts towards instilling justice take primacy? International actors took the debate to the U.N. Security Council, testing the waters of the peace versus justice puzzle with resolutions aimed at creating critical accountability measures. However, these efforts were quickly chilled by Russian and Chinese vetoes. In the wake of these vetoes, the Syrian conflict has become characterized by heavy reliance on the peace-first approach. However, there are persistent and ongoing efforts to introduce at least a measure of justice into the peace process, and the balance towards a peace with justice approach may yet tip in the future.

To track the efforts to weave justice into the peace process this section will discuss the positions of the parties and mediators toward justice in the Geneva peace negotiations; the actions of the Security Council and the

326. Nada Homsi \& Anne Barnard, Marked for 'De-Escalation,' Syrian Towns Endure Surge of Attacks, N.Y. TIMEs (Nov. 18, 2018), https://www.nytimes.com/2017/11/18/world/middleeast/syriade-escalation-zones-atarib.html.

327. See, e.g., S.C. Res. 2254, (Dec. 18, 2015)

328. Laura King \& Nabih Bulos, Syria May be in Ruins, but it Looks Like Assad 'Has Won the War Militarity', L.A. TIMES (Sept. 2, 2017, 4:00 AM), http:/www.latimes.com/world/middleeast/la-fgsyria-assad-2017-story.html; Tom O'Connor, How the U.S. Lost the War in Syria to Russia and Iran, NEwSWEEK (Oct. 11, 2017, 11:25 AM), http://www.newsweek.com/us-lost-war-syria-iran-russiawin ning-final-battle-674833.

329. O'Connor, supra note 328 (noting that the Syrian government army has retaken almost every major urban center [excluding Raqqa]) 
General Assembly, the initiatives of civil society and non-state actors, and the use of universal jurisdiction by some European states.

\section{Peace Negotiations}

The parties and mediators to the Syrian peace negotiations have a mixed record of attempts to introduce accountability measures into the negotiations. The Syrian Opposition has incorporated a measure of justice into their proposals, whereas the regime has not meaningfully addressed accountability. ${ }^{330}$ The U.N., meanwhile, has been lukewarm at best on the issue of accountability. ${ }^{331}$ In defense of justice, so to speak, the Syrian Opposition has staunchly refused any negotiation proposals that would permit the Assad regime to remain in power and thereby avoid accountability. The Syrian Opposition also has refused to countenance any proposals that would result in Assad or members of his regime securing de facto or de jure impunity. ${ }^{332}$

On the proactive side, the Opposition has been clear that any peace agreement should result in a tangible mechanism for accountability. The Opposition has produced a range of public material proposing various broad frameworks for accountability that could be incorporated into a peace agreement. ${ }^{333}$ For instance, in its September 2016 Vision Statement, the Syrian Opposition calls for a specific transitional justice committee composed of diverse and competent judges and lawyers, with the aim of balancing "between reconciliation efforts, on the one hand, and accountability, on the other." ${ }^{334}$ The committee is charged to fulfill international transitional justice standards, and develop mechanisms "to ensure accountability, reparation for the victims [ . . ] achieve institutional reform, propose mechanisms to investigate violations and crimes, and keep records related to human rights violations." ${ }^{335}$

330. Syrian Opposition Says Assad Must Go, SBS News, https://www.sbs.com.au/news/syrianopposition-says-assad-must-go (last updated Mar. 13, 2016).

331. Kailey Love, Will U.N.'s Accountability Mechanism Provide Justice in Syria?, WASH. REP. MIDDLE E. AFF., June-July 2017, at 62, https://www.wrmea.org/digital-issue/june/july-2017digital-flipbook.html.

332. See Nic Robertson \& Mohammed Tawfeeq, Bashar al-Assad Needs to Leave Before There's Peace, Syrian Opposition Says, CNN, https://www.cnn.com/2017/11/23/middleeast/syrianopposition-no-bashar-al-assad/index.html (last updated Nov. 23, 2017, 9:24 PM).

333. high Negotiations Comm'n, Executive framework for a polttical Solution BASED ON THE GENEVA COMMUNIQUÉ qT 44-45 (2016), http://english.riadhijab.com/userfiles/HNC\%20 Executive\%20Summary\%20-\%20English.pdf.

334. Id.

335. Id. \46 
Notably, the Syrian Opposition has not made any calls for the creation of an ad hoc or hybrid tribunal or other comprehensive accountability mechanism. The Opposition also has not yet proposed the application of retroactive jurisdiction of the ICC, by which the (future, transitional) Syrian state would submit to the ICC's jurisdiction to prosecute crimes within its jurisdiction taking place on Syrian territory from the onset of the conflict. ${ }^{336}$ The Assad regime, meanwhile, has rejected all claims for accountability for violations committed in the course of the conflict. Indeed, the regime has refused to address the general issue of accountability for war crimes in any genuine way. ${ }^{337}$ Rather, the regime has focused attention exclusively on accountability for supposed "terrorists," a term that the regime utilizes for entities that oppose the Assad government. ${ }^{338}$ The U.N., meanwhile, has taken a relatively tepid stance in the peace negotiations on issues relating to justice. In fact, none of the U.N. mediators have ever called for direct accountability in the context of the U.N.-led peace negotiations.

\section{The U.N. Security Council}

Given the lack of intensive engagement by the parties in relation to accountability measures in the context of the peace process, as well as larger uncertainty on the geopolitical level, it was unclear in the early stages of the Syrian conflict which approach within the peace versus justice puzzle would take hold. There were multiple efforts to introduce justice into the Syrian context via the U.N. Security Council, which reflected an early testing ground to determine which approach might come to take primacy in the Syrian conflict. However, few of these efforts at the U.N. Security Council found success; following this failure to move forward with important accountability mechanisms, the peace-first approach took rapid hold over the Syrian peace process.

For instance, in 2014, some members of the U.N. Security Council put forth a draft resolution to refer the situation in Syria to the ICC. ${ }^{339}$ The resolution received widespread public support by member states of the

336. Jennifer Trahan, New Paths to Accountability for Crimes in Syria and Iraq (Including ICC Jurisdiction Over Foreign Fighters), JUST SECURITY (Nov. 12, 2014), https://www.justsecurity.org/173 08/paths-accountability-crimes-syria-iraq-including-icc-jurisdiction-foreign-fighters/.

337. Zena Tahhan, Saving Syria: Is International Law the Answer?, AL JAZEERA (Mar. 16, 2017), http://www.aljazeera.com/indepth/features/2017/03/years-syria-accountability-free-zone-170312 $082121458 . \mathrm{html}$

338. Ben Hubbard, His Grip Still Secure, Bashar al-Assad Smiles as Syria Burns, N.Y. TimES (Sept. 17, 2016), https://www.nytimes.com/2016/09/18/world/middleeast/his-position-still-securebashar -al-assad-smiles-as-syria-burns.html.

339. U.N. SCOR, 7180th mtg., U.N. Doc. SC/1 1407 (May 22, 2014). 
United Nations. ${ }^{340}$ Within the Security Council, thirteen of the Council's fifteen member-states voted in favor of the resolution. ${ }^{341}$ However, both China and Russia vetoed the resolution. ${ }^{342}$

The U.N. Security Council has also attempted to lay the foundation for accountability in relation to the use of chemical weapons in Syria. ${ }^{343}$ In this regard the Security Council has experienced a mixed record. While the Security Council has succeeded in taking steps that allow for a measure of information-gathering, Russia has constrained these efforts by exercising its veto power to prevent a strong foundation for accountability. ${ }^{344}$

In August 2015, the U.N. Security Council issued Resolution 2235 to establish a joint mission between the Organization for the Prohibition of Chemical Weapons (OPCW), and the U.N. Joint Investigative Mechanisms (JIM) ${ }^{345}$ The mandate of the OPCW-JIM was to identify those responsible for the use of chemical weapons in Syria. ${ }^{346}$ In August 2016 and again in November 2016, the OPCW-JIM presented reports that, for the first time, attributed responsibility for the use of chemical weapons inside Syria to the Assad regime's armed forces. ${ }^{347}$ In a subsequent report, the OPCW-JIM determined that the Assad regime was responsible for the use of chemical weapons in the infamous attack on Khan Sheikhun on April 4, 2017.348

340. Ian Black, Russia and China Veto UN Move to Refer Syria to International Criminal Court, GuARDIAN (May 22, 2014, 11:07), https://www.theguardian.com/world/2014/may/22/russiachina-veto-un-draft-resolution-refer-syria-international-criminal-court.

341. U.N. SCOR, 7180th mtg., U.N. Doc. SC/1 1407 (May 22, 2014).

342. Id.

343. OPCW, Fact Sheet: OPCW - UN Joint Investigative Mechanism (Jan. 2017), https:/ /unoda-web.s3-accelerate.amazonaws.com/wp-content/uploads/2017/01/OPCW-JIM-FactSheet.pdf [hereinafter OPCW-UN].

344. Black, supra note 340; Michelle Nichols, Russia Casts 10th U.N. Veto on Syria Action, Blocking Inquiry Renewal, REUTERS (Nov. 16, 2017, 4:17 PM), https://www.reuters.com/article/usmideast-crisis-syria-chemicalweapons/russia-casts-10th-u-n-veto-on-syria-action-blocking-inquiryrenewal-idUSKBN1DG31I.

345. OPCW-UN, supra note 343.

346. Id.

347. OPCW Executive Council Adopts Decision Regarding the OPCW-United Nations Joint Investigative Mechanism Reports About Chemical Weapons Use in the Syrian Arab Republic, ORG. FOR PROHIBITION CHEMICAL WEAPONS (Nov. 11, 2016), https://www.opcw.org/news/article/opcwexecutive-council-adopts-decision-regarding-the-opcw-united-nations-joint-investigative-mechanismre ports-about-chemical-weapons-use-in-the-syrian-arab-republic/; U.S. Dep't of State, Fourth Report of the Joint Investigative Mechanism (2016).

348. U.N. Secretary-General, Letter dated Oct. 26, 2017 from the Secretary-General addressed to the President of the Security Council, U.N. Doc. S/2017/904 (Oct. 26, 2017) [hereinafter U.N. Secretary General, Letter]. The use of chemical weapons is a war crime under the Rome Statute of the ICC. See Rome Statute of the International Criminal Court art. 8(2)(b)(xvii)-(xviii), July 17, 1998, 2187 U.N.T.S. 91 (entered into force July 1, 2002). 
In relation to what would be done on the basis of attribution to the Assad regime, Virginia Gamba - the Head of the OPCW-JIM-declared that the OPCW-JIM "believes that those with effective control in the military units referred to in this report or others responsible for the use of chemicals as weapons in the Syrian Arab Republic must be held accountable." ${ }^{349}$ To support such accountability, the OPCW-JIM had the authority to conduct further investigations to determine the specific individuals involved in perpetrating or organizing the particular incidents in question. ${ }^{350}$

In response to this growing momentum towards accountability for the Assad regime for the use of chemical weapons, Russia cast a veto in October 2017 to prevent the renewal of the OPCW-JIM's mandate (which was scheduled to expire in mid-November 2017). ${ }^{351}$ As a result of the Russian veto, this second potential avenue for accountability through the UN Security Council was halted. ${ }^{352}$ From this pivotal point, the Syrian peace process evolved into a heavily peace-first oriented approach.

\section{The U.N. General Assembly}

In addition to efforts by the U.N. Security Council to introduce mechanisms for justice into the Syrian context, the U.N. General Assembly has created two primary initiatives. The first is the U.N. Commission of Inquiry (COI), which is mandated to investigate the commission of atrocities. The second is the International, Impartial, Independent Mechanism (IIIM), which was mandated to collect, analyze and preserve evidence of the commission of atrocities. ${ }^{353}$

The COI is a documentation mechanism with a mandate to investigate "all alleged violations of international human rights law since March 2011"

349. Press Release, Security Council, Security Council Considers Fourth Report by Joint Investigative Mechanism, U.N. Press Release DC/3668 (Oct. 27, 2016).

350. U.N. Secretary General, Letter, supra note 348.

351. Rodrigo Campos, Russia Vetoes Extension of Mission Probing Chemical Weapons Use in Syria, REUTERS (Oct. 24, 2017, 11:08 AM), https://www.reuters.com/article/us-mideast-crisis-syriaun/russia-vetoes-extension-of-mission-probing-chemical-weapons-use-in-syria-idUSKBN1CT25P.

352. Id.

353. Rep. of the H.R.C. on Its Seventeenth Special Session, U.N. Doc. A/HRC/S-17/2 (2011); Frequently Asked Questions on the International, Impartial and Independent Mechanism to Assist in the Investigation and Prosecution of Persons Responsible for the Most Serious Crimes Under International Law Committed in the Syrian Arab Republic Since March 2011 ('The Mechanism'), United Nations, https://www.un.org/News/dh/infocus/Syria/Frequently_asked_questions_on_IIIM.pdf (last visited Apr. 22,2018 ) [hereinafter $F A Q$ on the IIIM]. 
inside Syria. ${ }^{354}$ The COI has produced more than twenty reports since its inception in August 2011, documenting numerous violations of international law after interviewing thousands of witnesses and victims and analyzing significant physical evidence. ${ }^{355}$ Although the COI's mandate and purpose represents a fundamentally important task in laying the foundation for future prosecutions, the COI has struggled to succeed. Indeed, in August 2017, Carla Del Ponte-former prosecutor for the Yugoslavia and Rwanda Tribunals and one of the three members of the COI-resigned from the COI in protest of its failure to be effective. ${ }^{356}$ In particular, Ms. Del Ponte noted the serious impact of the COI's limited powers-without a more sufficient mandate, in her view the COI has "no possibility of seeking justice for victims." ${ }^{\text {357 }}$ In addition, Ms. Del Ponte pointed to the inaction of the U.N. Security Council in response to the COI's work. ${ }^{358}$ In describing her decision to leave the COI, Ms. Del Ponte said, "[i]t was all about the inaction of the security council because if you look at all the reports we have published, we have obtained nothing in terms of injustice. It is unbelievable." $\$ 359$

The IIIM is a mechanism under the purview of the U.N. General Assembly that was established in part due to Russia's repeated veto of Security Council efforts to refer Syria to the ICC. ${ }^{360}$ The IIIM prioritizes the collection, analysis, and preservation of evidence of human rights violations and war crimes-as opposed to directly engaging in investigations of the acts themselves. ${ }^{361}$ The COI is one of the many sources from which the IIIM obtains evidence. Additional sources for the IIIM include individuals, states, NGOs, and regional organizations. At the

354. Independent International Commission of Inquiry on the Syrian Arab Republic: About the Commission of Inquiry, UNITED NATIONS HUM. RTS. COUNCIL, http://www.ohchr.org/EN/HRBodies/ HRC/IICISyria/Pages/AboutCol.aspx (last visited Apr. 22, 2018) [hereinafter About the Commission of Inquiry].

355. Id.

356. Patrick Wintour, UN Syria Investigator Quits Over Concern About Russian Obstruction, GUARDIAN (Aug. 7, 2017, 14:17), https://www.theguardian.com/world/2017/aug/07/we-arpowerlessunsyria-investigator-carla-del-ponte-quits-over-lack-of-political-backing.

357. Id.

358. Id.

359. Id.

360. James Reinl, Could Syria's 'Prosecutor without A Tribunal' Work?, AL JAZEeRA (May 31, 2017), http://www.aljazeera.com/indepth/features/2017/05/syria-prosecutor-tribunal-work17052911 0910869.html.

361. Responding to Misconceptions Regarding the IIIM, SYRIA JUST. \& ACCOUNTABILITY CTR. (Aug. 2, 2017), https://syriaaccountability.org/updates/2017/08/02/responding-to-misconceptionsregarding-the-iiim/ (stating that the IIIM is headed by Catherine Marchi-Uhel, a seasoned former judge and war crimes attomey). 
present, the IIIM does not publicly disclose its findings and recommendations. ${ }^{362}$ The overarching policy of the IIIM is to essentially compile as much evidence of human rights violations and war crimes in Syria as possible and share that information with groups seeking to prosecute those crimes once it has vetted them for commitment to similar goals and standards as the IIIM. ${ }^{363}$

The IIIM is designed to support other entities engaging in prosecutorial efforts, including regional organizations and states pursuing options under universal jurisdiction, by sharing evidence with these entities. ${ }^{364}$ As a result, the IIIM could potentially increase the number of claims brought against perpetrators in Syria. ${ }^{365}$ The IIIM may also support any future prosecutions brought by the ICC in the event a new Syrian government submits to its retroactive jurisdiction, or prosecutions brought by a future hybrid court for Syria. ${ }^{366}$ Alternatively, if the IIIM deems that no such prosecution will effectively come to pass, the IIIM could release the information as part of a truth commission.

\section{Civil Society}

In addition to justice efforts put forth by the U.N., civil society has taken steps to introduce justice mechanisms into the Syrian context. In particular, despite the obstacles to direct accountability in the short-term, a range of groups are engaging in efforts to at the least establish a record of violations, and potentially to support future efforts for justice. ${ }^{367}$ Given the advent of new technology combined with burgeoning political will and resourcing, efforts to generate and preserve documentation have proliferated. ${ }^{368}$ In particular, civil society groups have utilized complex documentation mechanisms that could support accountability as well as a range of expanded justice mechanisms, including reparations, truth-telling, and memorialization. ${ }^{369}$ Taken in combination with U.N. documentation efforts such as those pursued by the COI, civil society documentation

362. Id. (adding that the IIIM will occasionally release periodic reports).

363. About the Commission of Inquiry, supra note 354.

364. FAQ on the IIIM, supra note 353.

365. Responding to Misconceptions Regarding the IIIM, supra note 361.

366. FAQ on the IIIM, supra note 353.

367. Citizens for Syria, Syrian Civil Society Organizations Reality and CHALLENGES 7-9 (Mhd. Bay trans., 2017), https://citizensforsyria.org/OrgLiterature/Syrian_CSOs_ Reality_and_challenges_2017-CrS_EN.pdf

368. Id. at 16 .

369. EReshnee Naidu, Syria Justice \& Accountability Centre, Syria: DOCUMENTATION AND ITS ROLE IN MEMORIALIZATION (2013), http://syriaaccountability.org/wpcon tent/uploads/SJAC-Documentation-Memorialization-Memo-2013_EN.pdf. 
efforts have contributed to a relatively rich pool of documentation material to support various future justice-related efforts.

For instance, the Commission for International Justice and Accountability (CIJA), is an international NGO that has been heavily engaged in gathering and processing a significant pool of evidence relating to atrocity crimes. ${ }^{370}$ In the course of its work, CIJA has gained access to more than 700,000 pages from Syrian Government's Intelligence and Security agencies. ${ }^{371}$ The purpose of CIJA is to lay the foundation for future prosecution "along the lines of Nuremberg," according to its Executive Director. ${ }^{372}$

Similarly, The Syria Justice and Accountability Centre (SJAC) is another entity that gathers intensive documentation in relation to atrocity crimes in Syria. ${ }^{373}$ SJAC analyzes the materials that it receives according to international law, with the purpose of promoting justice and accountability, and preserving evidence in order to "advance transitional justice and peacebuilding." 374

Furthermore, the Syrian Accountability Project (SAP) is an internationally-recognized platform that is documenting war crimes and crimes against humanity taking place in the Syrian context. ${ }^{375}$ The project is led by David Crane, the former Chief Prosecutor for the Special Court for Sierra Leone. ${ }^{376}$ In addition to gathering documentation, SAP analyzes the collected materials with reference to such relevant legal frameworks as international humanitarian law, international criminal law, and domestic Syrian criminal law. ${ }^{377}$

These efforts, while not in and of themselves necessarily sufficient for a comprehensive justice initiative, could provide fundamental support for diverse accountability mechanisms in the future.

370. Mark Kersten, Event: Prospects of Justice, Avenues for Accountability - Investigating War Crimes and Crimes Against Humanity in Syria, JuST. IN CONFLICT (Mar. 1, 2016), https://justiceinconflict_org/2016/03/01/event-prospects-of-justice-avenues-for-accountabilityinvestigati ng-war-crimes-and-crimes-against-humanity-in-syria/.

371. Stephanie Nebehay, Experts Say War Crimes Case Against Assad Government Growing, REUTERS (Mar. 15, 2017, 10:49 AM), https:/www.reuters.com/article/us-mideast-crisis-syriawarcrimes /experts-say-war-crimes-case-against-assad-government-growing-idUSKBN16M24Z.

372. Id.

373. About SJAC, SYRIA JUST. \& ACCOUNTABILITY CENTRE, https://syriaaccountability.org/ about/ (last visited Apr. 22, 2018).

374. Id.

375. The Syrian Accountability Project, SYRACUSE U. C. L., http://syrianaccountabilityproject .syr.edu/ (last visited Apr. 22, 2018).

376. Id.

377. Id 


\section{Regime Defectors}

Defectors from the Assad regime have also contributed significantly to the tapestry of justice mechanisms taking place in the Syrian context. The "Caesar Photographs," for instance, is a particularly striking documentation and awareness effort. ${ }^{378} \mathrm{~A}$ former Assad regime forensic photographer, who is called by the alias "Caesar," smuggled more than 55,000 photos of the bodies of detainees tortured or starved to death by the Assad regime. ${ }^{379}$ The photographs were a component of the Syrian security branch's efforts to develop a formal record of deaths in their detention centers; each body is marked with an identification number. ${ }^{380}$ The photographs have been highly effective as awareness-raising tools and establish a poignant record of atrocities taking place in Syrian. The photographs have already been utilized to support justice efforts. For example, in Spain, a case was lodged against the Syrian government for "state terrorism" on the behalf of a Syrian-Spanish woman who recognized her brother among the photographs of victims. ${ }^{381}$ Although the case itself has not resulted in a clear prosecutorial path, this step illustrates the potential utility of the photographs-and other related documentation efforts - in supporting future prosecutorial efforts, if and when the time is right.

These efforts to document atrocity crimes support preparation for future prosecutions, whether by the ICC, by a future hybrid tribunal, or by third party states under a theory of universal jurisdiction (discussed further below). The justice-related impacts of the Caesar project have already reverberated among policy makers, for instance prompting the United States Senate to introduce a bill in April 2017 after the Khan Sheikhoun gas attack by the Syrian regime. ${ }^{382}$ Among the measures included within the bill, was the call to establish a hybrid court for Syria to prosecute Assad and his regime. ${ }^{383}$ The bill was modeled on a previously-produced draft statute known as the "Chautauqua Blueprint" for an extraordinary tribunal for atrocity crimes in Syria, drawn up by chief prosecutors of several

378. Syria: Stories Behind Photos of Killed Detainees, HuM. RTS. WATCH (Dec. 16, 2015, 5:47 PM), https:/www.hrw.org/news/2015/12/16/syria-stories-behind-photos-killed-detainees.

379. Nebehay, supra note 371.

380. Priyanka Motaparthy \& Nadim Houry, Human Rights Watch, if the Dead Could Speak: Mass Deaths and Torture in SyRiA's Detention FaCilities (2015), https://www. hrw.org/sites/default/files/report_pdf/syrial 215web_0.pdf.

381. Nebehay, supra note 371.

382. Syrian War Crimes Accountability Act of 2017, S. 905, 115th Cong. (2017).

383. Id. 
international criminal tribunals under the initiative of the Public International Law \& Policy Group. ${ }^{384}$

\section{Universal Jurisdiction}

Perhaps the most creative of current efforts to pursue accountability in Syria is the steadily growing list of countries that are attempting to use universal jurisdiction to prosecute those responsible for atrocities. 385 Universal jurisdiction is the legal construct, which provides that any national court in any country can prosecute any individual from any country for the gravest of international law crimes, including "crimes against humanity, war crimes, genocide, and torture." 386 Although specific procedures vary, typically the prosecuting state needs the defendant to be within its territory before its domestic courts have the power to arrest and try that person. ${ }^{387}$ Prosecuting universal jurisdiction cases poses several steep logistical obstacles, such as gathering evidence and compelling appearances, which have rendered it an inefficient or otherwise morally questionable practice, even if it is occasionally an effective means of pursuing justice. ${ }^{388}$

In the Syrian context, Sweden, Finland, Germany, Switzerland, and Spain have had moderate successes with prosecuting certain individuals from the Assad regime's security forces, but have been unable to detain or convict higher-level officials or military officers. ${ }^{389}$ In the Spanish context, a case was filed against nine high-ranking security officers of the Assad regime, but the case was dismissed before it could go to trial due to domestic interpretation of the Spanish court's jurisdiction. ${ }^{390}$ In the

384. The Chautauqua Blueprint for A Statute for $A$ Syrian Extraordinary Tribunal to Prosecute Atrocity Crimes, SYRACUSE U.: INST. FOR NAT'L SECURITY \& COUNTERTERRORISM, http://insct.syr. edu/wp-content/uploads/2013/09/Chautauqua-Blueprintl pdf (last visited Apr. 22, 2018).

385. Noha Aboueldahab, The Perils of Impulsive Promises for Justice in Syria, BROOKINGS (Apr. 24, 2017), https://www.brookings.edu/blog/markaz/2017/04/24/the-perils-of-impulsive-promisesfor-justice-in-syria/.

386. Universal Jurisdiction, supra note 126.

387. Id.

388. Hussein Ibish, Universal Jurisdiction Raises as Many Problems as It Solves, NATIONAL (Sept. 28, 2013), https://www.thenational.ae/universal-jurisdiction-raises-as-many-problems-as-itsolves1.277149. In the post-WWII era when the concept was relatively new, Israeli Mossad Special Forces abducted Adolf Eichmann from Argentina for trial and eventual execution for war crimes and atrocity crimes. See id.

389. Aboueldahab, supra note 385 (noting Spain's investigation into Assad-sponsored state terrorism in 2013); Reinl, supra note 360 (noting Sweden's successful sentencing of a former Syrian opposition fighter to life in prison in Sweden for war crimes).

390. Adam Entous, A Photo of Her Brother's Corpse Popped Up on Her Phone. Now Syrian Officials Could be Put on Trial for War Crimes., WASH. POST (Feb. 2, 2017), https://www. 
Swedish context, meanwhile, a successful prosecution was completed, although the individual in question was a relatively low-level Syrian perpetrator and the evidence was sufficient to convict only for violating human dignity, as opposed to a crime attached to more serious punishment. ${ }^{391}$ In Germany, criminal complaints have been filed against high-level members of the Assad regime, under a theory of universal jurisdiction. ${ }^{392}$ The outcome of these complaints remains to be seen. In general, both the evidentiary collection problem and the means to compel suspects to appear before courts that are asserting universal jurisdiction continue to be challenges in Syria.

\section{The International Criminal Court}

Syria has signed but not ratified the Rome Statute, thus precluding the ICC's jurisdiction over the atrocity crimes being committed in Syria. ${ }^{393}$ Although Syria could be referred to the ICC via U.N. Security Council referral, as set forth above, such a referral was vetoed by Russia and China in $2014^{394}$ and almost certainly would be vetoed again. However, eventually, it may be possible to make use of retroactive ICC jurisdiction. When Assad does finally depart Syria (one way or another), the Syrian people, and the international community could pressure the new Syrian government to ratify the Rome Statute, and then prosecute Assad and other high-level perpetrators implicated in the Syrian war at the ICC..$^{395}$

washingtonpost.com/world/national-security/from-a-trove-of-grim-photos-a-case-against-assadsgovern ment/2017/02/01/728575d0-e8d7-1 le6-bf6f-30 lb6b443624_story.html?utm_term=.fla250139819; see also Simon Hooper, Torture Complaint Filed Against Syrian Officials in Spanish Court, NEWSDEEPLY: SYRIA DEEPLY (Feb. 3, 2017), https://www.newsdeeply.com/syria/articles/2017/02/03/torturecomplaintfiled-against-syrian-officials-in-spanish-court; Editorial, Spanish Court Drops Complaint Against Syrian Security Forces, REUTERS (July 21, 2017, 8:45 AM), https://www.reuters.com/article/us-mideast-crisissyria-spain/spain-court-drops-complaint-against-syrian-security-forces-idUSKBN1A61J1.

391. Anne Barnard, Syrian Soldier is Guilty of War Crime, A First in the 6-year Conflict, N.Y. TIMES (Oct. 3, 2017), https://www.nytimes.com/2017/10/03/world/middleeast/syria-war-crime.html.

392. Barbara UnmüBig, Opening Speech: Towards Accountability for International Crimes in Syria, HEINRICH BOLL STIFTUNG (Nov. 10, 2017), https://www.boell.de/en/2017/1 1/10/opening-speechtowards-accountability-international-crimes-syria.

393. Rome Statute of the International Criminal Court, supra note 348.

394. Rep. of the S.C., at 5, U.N. Doc. S/PV.7180 (2014); Peter Nadin, How the UN Security Council Failed Syria, INTERPRETER (Aug. 30, 2017, 18:09), https://www.lowyinstitute.org/theinterpre ter/how-un-security-council-failed-syria.

395. See Nebehay, supra note 371 ; Reinl, supra note 360. 


\section{CONCLUSION}

Ultimately, there are no easy answers in regard to the Syrian crisis, or to the fundamental puzzle of peace, justice, and the potential combination thereof. The case of Syria illustrates an immense weight of international crime balanced against the impossibility of immediate options for direct accountability-balanced, on the other side, against the immense importance of securing peace and halting hostilities. Ultimately, the last chapter on accountability in Syria remains to be written. Although after an initial period of certainty, the Syrian context thus far has come to reflect the predominance of a peace-first approach. Yet, the record is clear that, if nothing else, justice is persistent. Moreover, given the rich array of players in the Syrian context paired with the intensity of the conflict, sustainable peace is likely to be elusive without at least a measure of justice. The tilting balance, however, of both how much justice, and the nature of that justice, is unclear. It is possible that Syria will go the path of Colombia, with a mechanism that focuses, in its essence, on the transitional elements of justice. Alternatively, Syria may take on the Sierra Leonean model, with prosecutions for the most high-ranking perpetrators, and alternative mechanisms for mid-to-low-level perpetrators. Appeasement is unlikely to win the day in Syria, and although it is likely that a "justice-first" approach is no longer truly feasible in this challenging context, the menu of options for weaving justice into peace remain. It is possible that, through these, the long arm of justice will eventually reach the Syrian context. 